\title{
Characteristics of large animal models for current cell-based oral tissue regeneration.
}

\section{Mangione Francesca, DDS, PhD}

Université de Paris, URP 2496 Laboratory Orofacial Pathologies, Imaging and Biotherapies, Life Imaging Platform (PIV), UFR Odontology, France

AP-HP, Henri Mondor Hospital, Créteil, France

tel/fax: +33158076 724

francesca.mangione@u-paris.fr

Salmon Benjamin, DDS, PhD

Université de Paris, URP 2496 Laboratory Orofacial Pathologies, Imaging and Biotherapies, Life Imaging Platform (PIV), UFR Odontology, France

AP-HP, Bretonneau Hospital, Paris, France

AP-HP, Reference Center for Rare Disorders of the Calcium and Phosphate Metabolism, Filière OSCAR, Paris, France

tel/fax: +33158076 724

benjamin.salmon@u-paris.fr

EzEldeen Mostafa, DDS, MScD

OMFS-IMPATH Research Group, Department of Imaging and Pathology, Faculty of Medicine, University of Leuven and Maxillofacial Surgery Department, University Hospitals Leuven, Leuven, Belgium.

Department of Oral Health Sciences, KU Leuven and Paediatric Dentistry and Special Dental Care, University Hospitals Leuven, Kapucijnenvoer 33, 3000 Leuven, Belgium tel/fax: +32 16332954

mostafa.ezeldeen@kuleuven.be 
Jacobs Reinhilde, DDS, PhD

OMFS-IMPATH Research Group, Department of Imaging and Pathology, Faculty of Medicine, University of Leuven and Maxillofacial Surgery Department, University Hospitals Leuven, Leuven, Belgium.

Department of Dental Medicine, Karolinska Institute, Stockholm, Sweden

tel/fax: +3216332452

reinhilde.jacobs@uzleuven.be

Chaussain Catherine DDS, PhD

Université de Paris, URP 2496 Laboratory Orofacial Pathologies, Imaging and Biotherapies, Life Imaging Platform (PIV), UFR Odontology, France

AP-HP, Bretonneau Hospital, Paris, France

AP-HP, Reference Center for Rare Disorders of the Calcium and Phosphate Metabolism, Filière OSCAR, Paris, France

tel/fax: +33158076 724

catherine.chaussain@u-paris.fr

Vital Sibylle DDS, PhD (Corresponding author)

Université de Paris, URP 2496 Laboratory Orofacial Pathologies, Imaging and Biotherapies, Life Imaging Platform (PIV), UFR Odontology, France

AP-HP, Louis Mourier Hospital, DMU ESPRIT, Colombes, France

tel/fax: +33158076 724

sibylle.vital@u-paris.fr

Running title: Large animal models for oral tissue engineering

Keywords: stem cells, tissue engineering, animal model, pig, dog, sheep 
ABSTRACT

The recent advances in the field of cell-based therapeutics open promising perspectives for oral tissue regeneration. The development of large animal models, which overcome the limits of the rodent models and allow to emulate clinical situations, is crucial for the validation of regenerative strategies to move towards clinical application.

Currently, porcine, canine and ovine models are the mainly developed for oral regeneration and their specific characteristics have an impact on the outcomes of the studies.

Thus, this systematic review investigates the application of porcine, canine and ovine models in present cell-based oral regeneration, according to the species characteristics and the targeted tissue to regenerate.

A customized search of PubMed, EMBASE, Scopus, and Web of Science databases, from January 2015 to March 2020 was conducted. Relevant articles about cell-based oral tissues engineering in porcine, canine and ovine models were evaluated. Among the evaluated articles, fifty-eight relevant studies about cell-based oral regeneration in porcine, canine and ovine models matched the eligibility criteria and were selected for full analysis.

Porcine models, the most similar specie with humans, were mostly used for bone and periodontium regeneration; tooth regeneration was reported only in pig except for one study in dog.

Canine models were the most transversal models, successfully involved for all oral tissues regeneration and notably in implantology. However, differences with humans and ethical concerns affect the use of these models.

Ovine models, alternative to porcine and canine ones were mainly used for bone and, scarcely, for periodontium regeneration. The anatomy and physiology of these animals restrain their involvement.

If consistency was found in defects specificities and cells trends among different species animal models of bone, dentin-pulp complex or tooth regeneration, variability appeared in periodontium. 
Regeneration assessment methods were more elaborate in porcines and canines than in ovines.

Risk of bias was low for selection, attrition and reporting but unclear for performance and detection.

Overall, if none of the large animal models can be considered as an ideal one, they are of deemed importance for oral cell-based tissue engineering and researchers should consider their relevance to establish favorable conditions for a given preclinical cell-based therapeutics. 
IMPACT STATEMENT

This systematic review investigates porcine, canine and ovine models for current oral cell-

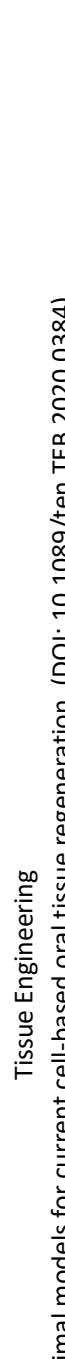
based regeneration procedures, and researchers could refer to it for the choice of the most pertinent pre-clinical model for a given cell-based therapeutics. 


\section{INTRODUCTION}

Injuries and pathologies affecting the oral region as well as lesions resulting from invasive and destructing therapeutic approaches can determine extensive loss of tissues and function. Moreover, due to the heterogeneity of the tissues of this area, their reconstruction is particularly complex ${ }^{1}$.

In recent years, thanks to the exponential growth of tissue engineering, new perspectives have been opened in cell-based oral regeneration ${ }^{2}$. In fact, the use of new sources of stem cells $^{2,3}$, the development of high-performance biomaterials and promising biotechnologies, such as 3D bioprinting ${ }^{3,4}$, allowed a considerable progress towards human application of cell-based oral tissue regeneration procedures. Prior to clinical trials, validation in animal models is required.

It has been established that rodents' substantial anatomic and physiologic dissimilarities with humans affect extrapolation of results from murine studies to patients. Thus, the development of large animal models, overcoming the limits of the rodent ones and allowing the reproduction of near-to-real clinical situations, plays a crucial role in the translation of cell-based regenerative procedures from bench to bedside ${ }^{5,6}$.

The identification of the most relevant animal model is a crucial step of the study conception. However, this selection is far from being a simple process, since multiple factors are at stake. Literature on oral regeneration reports large animal models that significantly contributed to the current knowledge on the field. In particular, non-human primates, porcines and canines have been involved, over decades, to investigate surgical procedures, pathogenesis of periodontal and endodontic diseases, guided-tissue regeneration and implantology ${ }^{7-9}$.

The identification and characterization of dental stem cells, in 2000, allowed a significant development of cell-based approaches of oral tissue regeneration ${ }^{10-12}$. Therefore, the above-mentioned animal species have been used to validate key models of bone ${ }^{3,9,13}$, periodontium ${ }^{14,15}$, dentin-pulp complex ${ }^{16-18}$ and tooth organ regeneration ${ }^{19}$, which opened the way to current research and still represent the benchmarks in the field. 
More recently, animal research faced considerable changes. Indeed, the introduction of the ARRIVE (Animal Research: Reporting of In Vivo Experiments) guidelines supported transparency and systematization in reporting on animal studies, addressing the problem of poor reproducibility of scientific findings ${ }^{20}$. Moreover, an emerging debate on the protection of animals used for scientific purposes led to substantial revisions of the existing regulation, notably introducing the 3Rs principle (Replacement, Reduction and Refinement) and restricting the use of specific species, with an actual full application by different countries only in the last few years.

This results in the exclusion of non-human primates' models for cell based oral tissue regeneration, leaving the choice of porcines, canines and ovines ${ }^{21-23}$.

Porcines are widely used due to their similitudes with humans in terms of anatomy (tab 1 , fig 1), physiology and pathology, as well as for ethical reasons. Nevertheless, their temperament can be difficult to manage ${ }^{5}$.

Canines are one of the most common large animal models for oral and dental regeneration, notably due to their familiar behavior and the comparable growth, physiology and pathology with humans. However, dogs are considered companion animals and their use in medical research is negatively perceived by society ${ }^{7}$ (tab 1 , fig 2 ).

As an alternative, the use of ovines increased over the last decade, but the ruminant nature leads to substantial anatomical differences in comparison with humans ${ }^{7}$ (tab 1, fig $3)$.

Hence, this review aimed to investigate porcine, canine and ovine models for current cellbased oral tissue regeneration procedures, in order to i) provide an exhaustive analysis of the present potential application of each model, and ii) support researchers in the choice of the most pertinent one for a given study, according to the animal characteristics and the tissue to regenerate. 


\section{METHODS}

\section{Search Strategy}

The review process followed the PRISMA (Preferred Reporting Items for Systematic Reviews and Meta-Analyses) guidelines ${ }^{24}$ and the protocol was registered in PROSPERO (International Prospective Register of Systematic Reviews) under the number CRD42020201550.

The peer-reviewed literature reporting about large animal models on most recent cellbased oral regeneration procedures was systematically searched in PubMed (National Library of Medicine, NCBI), Embase, Web of Science and Scopus databases, from January 2015 to March 2020. The following combination of key words was used: Oral AND (regeneration OR tissue engineering) AND stem cells AND (pig OR dog OR sheep). A manual review of articles' references was also performed.

\section{Eligibility criteria}

Inclusion criteria were: 1) cell-based oral tissues regeneration studies, 2) large animal studies, 3) English language available full text, 4) publication between 2015 and 2020.

Exclusion criteria were: 1) murine studies, 2) in vitro studies, 3) non-cell-based studies, 4) ectopic and semi-orthotopic regeneration models, 5) literature reviews.

Two independent reviewers (FM and SV) screened all relevant titles and abstracts against eligibility criteria. If the abstract did not provide sufficient information, the full text article was analyzed. A third reviewer (BS) was involved to resolve disagreements.

\section{Data Extraction and Analysis}

The selected articles were assigned, depending on the regenerated tissue, as follow: a) bone regeneration, b) periodontium regeneration, c) dentin-pulp complex regeneration, d) tooth/tooth-root regeneration studies. 
For each tissue, articles were subsequently classified according to the involved animal; reproduced clinical context/pathology, source of stem cells, scaffolds, follow-up and assessment techniques were considered.

\section{Assessment of quality of the studies}

Risk of bias for the included studies was evaluated by SYRCLE (SYstematic Review Centre for Laboratory animal Experimentation) risk of bias tool. The following criteria were used: 1) selection bias, 2) performance bias, 3) detection bias, 4) attrition and 5) reporting bias. Studies were scored with a "yes" for low risk of bias, "no" for high risk of bias, and "?" for unclear risk of bias by the two reviewers independently. Disagreements were resolved by a third reviewer (BS).

\section{RESULTS}

As presented in the flowchart based on PRISMA (fig 4), the initial search resulted in a total of 148 articles. Eight relevant publications were manually added from reference lists of the articles identified. After duplicate removal, a total of 123 articles was identified. The review and selection procedure resulted in the exclusion of 43 articles at title screeningstage and 11 articles based on the content of the abstract. Of the remaining 69 articles, 11 were excluded at the full-text reading stage for the following reasons: 1) 3 articles were not in vivo studies, 2) 1 article reported ectopic cell-based regeneration, 3) 3 articles reported studies not developed on large animal models, 4) 4 studies presented non cellbased regeneration. The entire selection process therefore resulted in a total of 58 articles, included in the present systematic review.

\section{Characteristics of the included studies}

Results are summarized in tables 2 to 5 (tab 2-5). Considering the regenerated tissues, 24 articles focused on bone ${ }^{25-48}, 17$ on periodontium ${ }^{49-65}, 10$ on dentin pulp-complex ${ }^{66-75}$ and 7 on tooth or tooth root $^{76-82}$. Regarding bone regeneration, 8 studies developed a porcine model $^{25-32}, 14$ a canine ${ }^{33-46}$ and 2 an ovine one ${ }^{47,48}$. Eight studies reported periodontium regeneration in pig $^{49-56}, 8$ in $\operatorname{dog}^{57-64}$ and 1 in sheep ${ }^{65}$. Among the articles about dentin 
pulp-complex regeneration, 2 studies were developed in pig $^{66,67}$ and 8 in $\operatorname{dog}^{68-75}$. Except for 1 canine model $^{82}$, in all the studies, tooth or tooth root regeneration was reported in porcines $^{76-81}$.

\section{a) Bone regeneration (tab 2)}

\section{Porcine models}

The clinical situations were exclusively acute defects such as mandible non critical $^{26}$ and critical size bone defects ${ }^{27,29,31}$, mandible extraction socket ${ }^{32}$, alveolar cleft $^{25,30}$ as well as ramus and condyle defects ${ }^{28}$.

Employed cells were mostly porcine cells such as pMSCs ${ }^{25,30,32}$, pBMSCs ${ }^{26,29,31}$ and pADSCs $^{28}$, except in one study in which human DPSCs were used ${ }^{27}$. The used scaffolds were PLGA $^{25,29,30}, \mathrm{~b}-\mathrm{TCP}^{26,27}$ and decellularized bone scaffolds ${ }^{28,31}$. In one article, cell sheets were involved $^{32}$.

Follow-up was performed during 4 weeks (or 30 days) ${ }^{25,31}, 6$ weeks $^{32}, 8$ weeks $^{26,27}, 12$ weeks (or 90 days) ${ }^{29,30}$ and 6 months ${ }^{28}$.

Regenerated tissues were assessed by histology in all studies ${ }^{25-32}$, in association with CT and/or $\mu \mathrm{CT}$ evaluation ${ }^{25,28-31}$, immunohistochemistry ${ }^{25,26,30}$, histomorphometry ${ }^{26,27,32}$, mechanical tests ${ }^{30}$ and fluorescence microscopy ${ }^{32}$.

\section{Canine models}

The studies focused on acute models of mandible peri-implant bone defects $33,39,43,45,46$, mandible non critical $^{34}$ and critical size bone defects ${ }^{37,42,44}$, alveolar cleft ${ }^{35}$, bilateral sinus lift $^{38}$, mandible segmental defect ${ }^{41}$. Two studies developed chronic mandible peri-implant bone defects ${ }^{36,40}$.

The employed cells were $\mathrm{cBMSCs}^{34,35,38,41,45}$, rhPDGF- $\mathrm{cBMSCs}^{39}, \mathrm{cADSCs}^{37,43}, \mathrm{cEPCs}^{42}$, BMP2-cADSCs $^{40}$, BMP2-cPDLSCs $^{36}, \mathrm{cPDLSCs}^{46}$. Only 2 studies used hADCs ${ }^{33,44}$. Cell sheets were used in 2 articles $^{41,46}$.

Cells were seeded into various scaffolds such as b-TCP $35,39,45$, TCP $^{40}$, HA-TCP ${ }^{33,44}$, TCPfibronectin ${ }^{37,43}$, PLGA $^{44}, \mathrm{~b}$-TCP coated with PLGA releasing VEGF ${ }^{42}$, FDB $^{41}$ and HA-collagen ${ }^{36}$. 
The follow-up was performed during 4 weeks $^{33}, 8$ weeks $^{41,42,44}, 11$ weeks $s^{46}, 12$ weeks or 3 months ${ }^{35-37,39,43,45}, 16$ weeks $^{34}, 6$ months $^{38}$ and 10 months $^{40}$.

In 13 out of 14 studies, assessment was made by histology and histomorphometry ${ }^{33-40,42-46}$; these techniques were also associated with 2D and/or 3D $(\mu \mathrm{CT})$ radiographic analysis $^{38,40,41,44,45}$, BIC evaluation $33,36,39,40,43,45,46$, hardness mechanical tests ${ }^{34,38}$ and fluorescence microscopy ${ }^{39}$. Only one study evaluated regenerated tissues by combining histology, immunohistochemistry and radiographies ${ }^{41}$.

\section{Ovine models}

One study focused on sinus lift ${ }^{47}$, the other one on acute mandible segmental bone defect $^{48}$. oMSCs ${ }^{47}$ and oBMSCs ${ }^{48}$ were used respectively associated with autologous serum and BBM scaffold. Follow-up was made for $16^{47}$ and 32 weeks ${ }^{48}$.

Histology and histomorphometry were performed in both studies ${ }^{47,48}$, in one case also combined with $\mathrm{CT}$ and $\mu \mathrm{CT}$ evaluations ${ }^{48}$.

\section{b) Periodontium regeneration (tab 3)}

\section{Porcine models}

The experimental models of periodontitis reproduced acute or acute-chronic mandibular class II furcation defects ${ }^{53,56}$, acute-chronic maxillary and/or mandibular alveolar 3 walls bone defects ${ }^{49-52,54,55}$.

Porcine cells such as pMSCs ${ }^{50}, \mathrm{pADCs}^{56}$ and $\mathrm{pPDLSCs}^{53}$ were used in 3 studies. Human cells like hPDLSCs transfected with $\mathrm{HGF}^{49}$, hDPSCs ${ }^{52}$, IGFBP5-hMSCs ${ }^{51}$ and human SCAPS ${ }^{54}$ transfected or not with SFRP2 ${ }^{55}$ were employed in the other articles.

Cells were seeded into fibrin gel complex ${ }^{56}$, IL1-HyA-sECM ${ }^{50}$ hydrogel and collagen ${ }^{53}$ scaffolds. In the other studies cells were injected ${ }^{49,51,52,54,55}$ and in one case also associated with cells sheets ${ }^{52}$.

The follow-up was performed during 4 weeks $^{56}, 12$ weeks or 3 months ${ }^{49,51-55}$ and 16 weeks ${ }^{50}$. 
Assessment was made by clinical, radiographic and histological evaluations in 5 studies $^{49,50,52,54,55}, 3$ out of which also performed histomorphometry ${ }^{49,54,55}$.

One article presented clinical, photographic and histological but no radiographic analysis ${ }^{51}$. Two articles reported histology and histomorphometry respectively associated with $\mu \mathrm{CT}$ and immunohistochemistry ${ }^{56}$ as well as fluorescence microscopy ${ }^{53}$ but no clinical evaluation.

\section{Canine models}

The experimental models of periodontitis reproduced acute mandible alveolar bone dehiscence $^{59}$ and maxillary-mandibular class II furcation defects ${ }^{63}$, acute-chronic mandible class III or II furcation defects ${ }^{58,60}$, mandibular alveolar bone dehiscence ${ }^{62,64}$, as well as chronic maxilla and mandible alveolar bone defects ${ }^{61}$. One model of tooth reimplantation was reported ${ }^{57}$.

The employed cells were cBMSCs ${ }^{58,59,63}$ also transfected with GFP ${ }^{63}$ or TRL2 ${ }^{64}$, cESEHT with $\mathrm{PAB}^{60}, \mathrm{cPDLSCs}^{57}, \mathrm{~b}-$ defensin-3-cPDLCs ${ }^{61}$. Human cells (hPDLCs) were used once ${ }^{62}$.

One study used cells sheets ${ }^{61}$. Each article reported a different scaffold material such as atelocollagen with b-TCP ${ }^{58}, \mathrm{HA}$-collagen ${ }^{59}$, collagen $^{64}, \mathrm{BCP}^{62}, \mathrm{PRP}$ and fibrin glue ${ }^{63}$, decellularized dental root with calcium phosphate (CaP)-fibronectin coating ${ }^{57}$. In 1 study grafting materials were not specified ${ }^{60}$.

The follow-up was performed during 2 weeks $^{64}, 8$ weeks $^{57,58,60,61,63}, 12$ weeks $^{62}$ and 6 moths ${ }^{59}$.

The assessment was performed in half of the studies by histology and histomorphometry ${ }^{58-60,63}$ also associated with $\mu \mathrm{CT}$ analysis ${ }^{59}$, immunohistochemistry and TRAP $^{58}$. Histology and $\mu \mathrm{CT}$ analysis ${ }^{57,62,64}$, in 1 case also associated with fluorescence microscopy ${ }^{62}$, were reported. In 1 study assessment consisted of histology and immunohistochemistry ${ }^{61}$. 
Ovine model

The periodontal defect was an acute dehiscence in the mandibular premolar-molar area. Ovine PDLSCs and BMSCs sheets were used associated with polycaprolactone biphasic scaffold.

The follow-up was 10 weeks. The assessment of regenerated tissues was made by histology, histomorphometry and $\mu \mathrm{CT}^{65}$.

\section{c) Dentin-pulp complex regeneration (tab 4)}

\section{Porcine models}

One study focused on partial pulp regeneration ${ }^{66}$, the other one investigated total pulp regeneration ${ }^{67}$. In both cases, upper and lower mature multirooted teeth were involved and the pulp defects were acutely induced.

Porcine DPCs and pDPSCs were used. The cells were seeded in a nanopeptide ${ }^{66}$ and in HyA or Collagen hydrogels ${ }^{67}$ respectively.

The follow-up was performed during 21 days ${ }^{66}$ and 4 months ${ }^{67}$.

In one study assessment was made by histology, immunohistochemistry, $\mu \mathrm{CT}$ and histomorphometry ${ }^{66}$, in the other one histological, immunohistochemical and 2D radiographic analysis were performed ${ }^{67}$.

\section{Canine models}

Models of partial pulp regeneration involving upper and lower multirooted teeth were reported in 2 studies $^{71,75}$. Authors used immature ${ }^{71}$ and mature ${ }^{75}$ teeth respectively. Five studies focused on total pulp regeneration ${ }^{68-70,73,74}$. The involved teeth were upper and lower mature incisors ${ }^{69,70,74}$, upper immature incisors ${ }^{73}$ as well as upper and lower mature multirooted teeth ${ }^{68}$. Only 1 study evaluated a model of pulp chamber floor perforation in upper and lower mature premolars ${ }^{72}$. Expect for 1 article $^{73}$, dentin-pulp complex defects were acutely generated.

Regarding the source of cells, cDPSCs ${ }^{68,71-73}$, (G-CSF)MDPSCs ${ }^{69,70,74}$ as well cBMSCs $^{75}$ were involved. 
Cells were implanted with atelocollagen scaffold ${ }^{69,70,74}, \mathrm{PRF}^{68}$, $\mathrm{TDM}$ or $\mathrm{TCP}^{72}$, gelatin sponge associated with simvastatin ${ }^{71}$ and chitosan hydrogel releasing VEGF-2, PDGF, NGF and $\mathrm{BMP}^{73}$. In 1 study cells were injected ${ }^{75}$.

Follow-up was performed during 2 weeks $^{69}, 8$ weeks $^{68}, 9$ weeks $^{75}, 10$ weeks $^{71}, 3$ months or 12 weeks $^{72,74}, 4$ months $^{73}$ and 6 months $^{70}$.

Histological assessment was reported in all studies ${ }^{68-75}$, associated with histomorphometric analysis $^{68,69,72}, 2 \mathrm{D}$ radiographies ${ }^{71,73} \mathrm{MRI}^{70}$, in situ hybridization ${ }^{69}$, immunohistochemistry ${ }^{69}$ as well as blood and urine tests ${ }^{75}$.

\section{d) Tooth or tooth root regeneration (tab 5)}

\section{Porcine models}

Three studies focused on tooth root regeneration in the mandibular incisor ${ }^{78}$ and premolar area $^{76,77}$. Three articles described whole tooth regeneration ${ }^{79-81}$ in the upper incisor and premolar region ${ }^{81}$, in lower canine and premolar region ${ }^{80}$ as well as in lower premolar and premolar region $^{79}$.

Porcine DFCs transfected or not with GFP were used in 2 studies ${ }^{76,77}$. One article described re-associated tooth germs implantation associated with BMSCs systemically infused ${ }^{81}$. In 2 cases, pDPSCs were combined with pPDLSCs sheets ${ }^{78}$ or epithelial cells from gingiva $^{79}$. In 1 study pECs were associated with hDPCs and hUVEC1 ${ }^{80}$.

The scaffolds in which cells were seeded were $\mathrm{TDM}^{76,77}, \mathrm{HA}-\mathrm{TCP}^{78}$, gelatin-chondroitinhyaluronan scaffold ${ }^{79}$ and $\mathrm{dTB}^{80}$.

The follow-up was performed during 12 weeks $^{76}, 150$ days $^{81}, 6$ months $^{77,78,80}$ and 13,5 months ${ }^{79}$.

Histology, radiography $(2 \mathrm{D}, \mu \mathrm{CT}, \mathrm{CT}, \mathrm{CBCT})$ and immunohistochemistry analysis were reported in 5 studies $^{76,77,79-81}$, in 1 of which clinical oral assessment was performed too ${ }^{77}$.

In only 1 study, clinical, radiographic $(\mathrm{CT}, \mu \mathrm{CT})$, biomechanical and elemental analysis were combined $^{78}$. 
Canine model

Whole tooth regeneration was performed in lower premolar area. The regenerated teeth underwent orthodontic traction to test periodontal ligament remodeling.

Canine tooth buds cells were used. The follow-up consisted of 6 months plus 1 month for orthodontic treatment evaluation. The assessment was made by histology, 3D radiography (СBCT and $\mu \mathrm{CT}$ ), scanning electron microscopy and energy dispersive X-ray spectroscopy ${ }^{82}$.

\section{Assessment of quality of studies}

In $98 \%$ of the studies a low risk of selection bias (baseline characteristics) was found ${ }^{25-42,44-}$ 64,66-82. Performance bias was considered unclear in $98 \%$ of cases ${ }^{25-47,49-82}$, because no information about random housing was given. Random outcome assessment was scored as low risk for $24 \%$ of the studies $25-29,33,34,36-40,42,43,46-48,50,52,54,57-60,62-74,76-82$ and unclear for the rest of them. In none of studies blinding was described and the risk was rated as unclear $^{25-82}$. A low risk of attrition and reporting bias was estimated for all studies ${ }^{25-82}$ (fig 5, supplemental fig 1-4).

\section{DISCUSSION}

\section{Large animal models according to regenerated tissues}

\section{$\underline{\text { Bone regeneration }}$}

Our research highlights that porcine, canine and ovine models were developed for cellbased regeneration of acute critical maxillary and mandible jawbone defects, mimicking congenital lack of tissues as well as traumatic or postsurgical sequels, such as clefts or segmental osteotomies ${ }^{25-48}$. Moreover, procedures requiring long healing process were possible, since reported follow-up went from 1 month even up to 10 months ${ }^{25-48}$.

As supported by broad literature on cell-based bone regeneration in large animals ${ }^{83}$, these models make up for multiple limitations of widespread murine calvarial defects, such as the impossibility to perform long term studies, the lack of biomechanical loading and faster tissue healing than in humans $s^{5,84,85}$. 
In accordance with previous studies ${ }^{86-88}$, it appears that porcine models are preferred to the other models for higher challenge bone regeneration procedures, because of their similarities with humans, in terms of anatomy, morphology, healing, remodeling and mechanical properties ${ }^{25,28,30}$.

For instance, Bhumiratana et al. demonstrated regeneration of ramus-condyle unit by using an autologous, anatomically shaped, living graft, made by decellularized bovine trabecular bone and pADSCs ${ }^{28}$.

Furthermore, since congenital clefts occurring in pig resemble those in humans, Caballero et al. reported porcine alveolar cleft regeneration using porcine umbilical cord mesenchymal stem cells sheets associated with nano-microfiber PLGA scaffold ${ }^{25,30}$.

In implantology, canines play a key role ${ }^{14,89}$. In this review, numerous peri-implant bone defects and re-osteointegration models were identified $33,36,39,40,43,45,46$; in fact, dogs' bone turnover, composition and mechanical properties are the most similar to humans among large animal models, even if jaws show a denser and more resistant bone ${ }^{7,89}$.

Even if ovine models of cell-based bone regeneration are reported in literature ${ }^{90,91}$, in our research, only two studies developed maxillary sinus lift and mandible segmental osteotomy. Indeed, ovine bone dissimilarities with humans such as higher density and mechanical resistance, as well as age related changes in structure and remodeling can limit the relevance of ovine models for follow-up studies ${ }^{7,14,25,89,92}$.

\section{Periodontium regeneration}

Since murine periodontium and bacterial resistance sensibly differ from humans, porcine, canine and ovine models of periodontitis are developed ${ }^{14,89}$.

In this review, similar types of periodontal lesions were reported in pig and dog. However, variability in defects' standardization and follow-up was encountered between the two species.

Only one study developed an acute ovine model of mandible dehiscence ${ }^{65}$. Sheep periodontium displays constant cement apposition as a compensation response to teeth ware which is typical in ruminants ${ }^{14}$. Hence, this periodontal physiology is likely to have an 
impact on regeneration mechanisms, which represents a non-neglecting bias for the potential extrapolation to patients ${ }^{14,92,93}$.

\section{Dentin-pulp complex regeneration}

Regenerative endodontics opens up the perspective of an alternative to millions of endodontic treatments each year ${ }^{94-96}$.

Validated in murine ectopic models, dentin-pulp regeneration is hardly performed orthotopically due to frequent dental fractures and differences with human pulp reparation process. Thus, large animals are required to address these limitations ${ }^{97,98}$.

Interestingly, despite a more important similarity of pig dental anatomy and physiology with humans in comparison with dogs, mostly canine and only two porcine models were developed $66-75$.

Besides, in both animals, partial and total dentin-pulp complex regeneration procedures, involving upper and lower mature or immature single-rooted or multi-rooted teeth, were evaluated, meaning that several clinical situations can be reproduced in these models. In addition, in dog also a pulp chamber floor perforation model was reported ${ }^{72}$.

However, regarding partial pulp regeneration, contrasting findings were reported. In 2017, our team demonstrated, after 3 weeks follow-up, no pulp regeneration but reparative osteodentinogenesis in minipig mature multi-rooted permanent teeth by implanting pDPCs into a self-assembling injectable hydrogel scaffold in a pulpotomy model ${ }^{66}$. In dog, after 9 to 10 weeks, normally organized pulp tissue with a complete dentin bridge was found in single-rooted immature teeth as well as in multirooted mature teeth, using cDPSCs seeded in a gelatin sponge scaffold releasing simvastatine and injected cBMSCs respectively $^{71,75}$.

In line with previous studies ${ }^{99-102}$, canine models as well as the only porcine model of total pulp regeneration used autologous DPSCs ${ }^{67-70,73,74}$ mostly combined with collagen-based scaffolds ${ }^{67,69,73,74}$ in mature single-rooted upper and lower teeth ${ }^{69,70,73,74}$. However, the role of neoangiogenesis was solely investigated in dog, since cells were constantly conditioned or associated with angiogenetic factors. One could assume that such a difference in 
regenerative environments between animal models influenced the duration of the regenerative process ${ }^{84}$ since functional dentin-pulp complex was obtained after 4 months in pig ${ }^{67}$ and in 2 weeks to 6 months in $\operatorname{dog}^{68-70,73,74}$.

\section{$\underline{\text { Tooth regeneration }}$}

The challenging regeneration of tooth organ, which depends on the recombination of dental mesenchymal and epithelial stem cells, has been demonstrated in several animal models ${ }^{19,103,104}$. However, it has been shown that the dental functionality can only be assessed in large animals ${ }^{19,103}$.

In this review, tooth regeneration was reported in numerous porcine models ${ }^{76-81}$ and in only one canine model ${ }^{82}$. In particular, in pig, consistently with literature ${ }^{87,105,106}$, two procedures were studied: tooth-root and whole tooth regeneration. Functional bio-root formation was reported after implantation of HA/TCP/DPSC/PDLSC sheets ${ }^{78}$. Positives outcomes were obtained also combining TDM with minipig DFCs ${ }^{76,77}$. Whole single-rooted tooth regeneration was achieved by allo-transplanted re-associated tooth germs into minipigs jaws associated with systemic infusion of pBMMSCs as well as recellularized dTBs seeded with porcine dental epithelial cells, human dental pulp cells, and human umbilical vein endothelial cells, with an average follow-up of 6 months ${ }^{80,81}$.

In line with porcine models, premolar regeneration was achieved, in dog, 6 months after transplantation of bioengineered tooth germs made with autologous germs cells, in the lower jaw. Periodontal functionality was eventually confirmed by 4 weeks long orthodontic traction $^{82}$.

\section{Defects characteristics}

The reported oral tissues defects were mostly acute $25-35,37-39,41-48,53,56,57,59,62,63,65-72,74,75$. Indeed, surgically made lesions imply standardized configuration, clear understanding of the regenerative process and reduced experimental time. However, these models reproduce simplified regenerative environments ${ }^{89}$.

The bacterial component of oral pathologies was considered in few chronic ${ }^{36,40,61,64,73}$ or acute-chronic $^{49-52,54,55,58,60}$ models of periimplantitis, periodontitis and pulp necrosis. 
Certainly, these models, requiring time-consuming procedures, result in a variable degree of standardization of the defect, complicating the comparisons between studies ${ }^{89}$.

\section{Stem cells trends}

The pertinence of an animal model for oral tissue-engineering also relies on the potentiality to study different stem cell populations/sources. Thus, the accessibility to autologous stem cells as well as the feasibility of allogenic grafts are crucial criteria of choice.

Similar trends of cell-based bone regeneration were reported in all large animal models with comparable results. In fact, most of the studies demonstrated increased bone formation in critical size defects using autologous BMSCs, ADCs or MSCs principally seeded into b-TCP, PLGA or demineralized bone matrix scaffolds $25,26,28-32,34,35,37-45,47,48$.

Unlike the ovine models, in pig and dog large jaws reconstruction and peri-implant defects were also successfully treated by implanting autologous or human ADSCs and/or MSCs coseeded with endothelial progenitor cells associated with b-TCP and/or PLGA $25,28-30,32,33,40,42-$ ${ }^{44}$ as well as autologous or human stem cells from dental tissues alone or combined with bTCP or HA/collagen ${ }^{27,36,46}$.

A substantial discrepancy between trends of periodontal defects regeneration was found; in fact, in pig hMSCs, hPDLSCs and hSCAPS ${ }^{49,51,52,54,55}$ were mostly involved, while in dog and sheep mostly autologous mesenchymal stem cells or periodontal ligament stem cells and no SCAPs were used ${ }^{57-61,63-65}$. Moreover, porcine stem cells were mostly injected or used as sheets $49,51,52,54,55$, whereas in dog and sheep they were implanted combined with a large variety of grafting materials ${ }^{57-61,63-65}$ which even more complicate comparisons within studies ${ }^{28,89}$.

Regarding pulp and root or whole tooth regeneration, in both porcine and canine models mostly autologous dental stem cells ${ }^{66-71,73-79,82}$ were used which is coherent with the manageable accessibility to this source of cells in animals showing similar loco-regional anatomy and dental eruption physiology with humans $s^{6,7,25}$. 


\section{Regeneration assessment}

Regeneration assessment is essential for the validation of tissue-engineering procedures. A pertinent large animal model should allow an appropriate follow-up duration for a given procedure as well as the quali-quantification of the newly formed tissues and their relation with the surrounding structures ${ }^{7,25}$.

In the porcine, canine and ovine studies included in this systematic review, mineralized as well as non-mineralized oral tissues regeneration was assessed within periods even up to 13,5 months and the analysis was performed by similar approaches in the three models.

Overall, most of the studies reported histological, histomorphometric and/or 2D/3D imaging analysis ${ }^{25-40,42-60,62-73}$. Regardless for the $\mu \mathrm{CT}$, which is an ex-vivo technique, imaging assessment was made by technologies currently used in patients such as intraoral 2D radiography, $\mathrm{CT}, \mathrm{CBCT}$ and $\mathrm{MRI}$. Furthermore, reiterative blood and urine tests, impossible in murine, were reported ${ }^{74}$, which highlights the importance of large animals for mimicking clinical conditions ${ }^{5,25}$.

However, specific animals' characteristics, data/means unavailability and the necessity to contain the number of samples, according to the $3 R$ s principle, give raise to some technical boundaries restraining tissues assessment ${ }^{5,25,66,107}$.

For example, immunohistochemistry was not constantly performed in pig or dog and not reported at all in sheep models; indeed, some tissue-specific markers cannot be revealed, because of the lack of suitable antibodies. Moreover, due to their size, specimens require even up to several months for the demineralization prior to histological analysis. Thus, aggressive acids or techniques used to accelerate the process can impair antigenic sites and limit antibodies bond ${ }^{66,107}$.

\section{Risk of bias}

Overall, the included studies presented a low risk of bias in terms of animals' selection (notably ARRIVE guidelines were respected), attrition and reporting. However, poor reporting in terms of performance and detection affected evaluations and synthesis of results. Thus, SYRCLE guidelines should be followed especially for randomization protocols, 
animal housing facilities and blinding, which could improve homogeneity of large animal models' trials in oral cell-based regeneration.

\section{CONCLUSION}

The development of large animal models for oral tissue engineering is crucial for human application. Pig, dog and sheep are the most relevant species allowed by current regulation, but they can have significant drawbacks, including functional dissimilarities when compared to the human craniofacial and dental anatomy.

Porcine models, the most similar with humans, were successfully developed for bone and periodontium regeneration, but very little was demonstrated about dentin-pulp complex. Interestingly, tooth/tooth root regeneration was reported only in pig, except for one canine study.

Canines are indeed the most transversal models as they showed positive outcomes for the regeneration of bone, in particular in implantology, as well as periodontium and dentinpulp complex; however, canines substantially differ from humans and ethical concerns arise from their involvement.

Ovines are the least developed models, as they emerged as an alternative to dog and pig. Besides the economic and ethical advantages, these animals display essential dissimilarities with humans. Hence, ovine were mainly used for bone and very little for periodontium regeneration.

If a consistency was found in defects specificities and cells trends among different species animal models of bone, dentin-pulp complex or tooth regeneration, a variability appeared in periodontium.

Indeed, methods of regeneration assessment were more elaborate in porcines and canines than in ovines.

Overall, preclinical models display specific properties to take into account for oral tissues engineering. Thus, studies of different regenerative procedures should be related to the choice of the most pertinent large animal model for a given cell-based therapeutics. 


\section{AUTHORS' CONTRIBUTION}

Conceptualization, F.M. and S.V.; writing/original draft preparation, F.M.; writing/review and editing, F.M., S.V., M.E., B.S., C.C. and R.J.

\section{FUNDING STATEMENT}

This research received no external funding.

\section{DISCLOSURE STATEMENT}

No competing financial interests exist

\section{ACKNOLEDGMENTS}

We would like to thank Elisabeth Dursun for her support as well as Fondation des Maladies Rares. 


\section{References}

1. Smirani R, Rémy $M$, Devillard R, Naveau A. Engineered prevascularization for oral tissue grafting: a systematic review. Tissue Eng Part B Rev. 2020;26:383-398.

2. Matichescu A, Ardelean LC, Rusu LC, Craciun D, Bratu EA, Babucea M, Leretter M. Avanced biomaterials and techniques for oral tissue engineering and regeneration-a review. Materials (Basel). 2020;13:5303.

3. Hutchings $G$, Moncrieff $L$, Dompe $C$ et al. Bone regeneration, reconstruction and use of osteogenic cells; from basic knowledge, animal models to clinical trials. J Clin Med. 2020;9:139.

4. Ong CS, Yesantharao $P$, Huang $C Y$, Mattson G, Boktor J, Fukunishi $T$, Zhang $H$, Hibino N. 3D bioprinting using stem cells. Pediatr Res. 2018;83:223-231.

5. McGovern JA, Griffin M, Hutmacher DW. Animal models for bone tissue engineering and modelling disease. Dis Model Mech 2018;11.

6. Štembírek J, Kyllar M, Putnová I, Stehlík L, Buchtová M. The pig as an experimental model for clinical craniofacial research. Lab Anim 2012;46:269-79.

7. Pearce Al, Richards RG, Milz S, Schneider E, Pearce SG. Animal models for implant biomaterial research in bone: a review. Eur Cell Mater. 2007;13:1-10.

8. Weinberg MA, Bral M. Laboratory animal models in periodontology. J Clin Periodontol. 1999;26:335-40.

9. Ripamonti U, Herbst NN, Ramoshebi LN. Bone morphogenetic proteins in craniofacial and periodontal tissue engineering: experimental studies in the non-human primate Papio ursinus. Cytokine Growth Factor Rev. 2005;16:357-68.

10. Gronthos S, Mankani M, Brahim J, Robey PG, Shi S. Postnatal human dental pulp stem cells (DPSCs) in vitro and in vivo. Proc Natl Acad Sci U S A. 2000;97:13625-30.

11. Tatullo M, Marrelli M, Shakesheff KM, White LJ. Dental pulp stem cells: function, isolation and applications in regenerative medicine. J Tissue Eng Regen Med. 2015;9:1205-16.

12. La Noce $M$, Paino F, Spina A et al. Dental pulp stem cells: state of the art and suggestions for a true translation of research into therapy. J Dent. 2014;42:761-8. 
13. Liu M, Lv Y. Reconstructing bone with natural bone graft: a review of in vivo studies in bone defect animal model. Nanomaterials (Basel). 2018;8:999.

14. Fawzy El-Sayed KM, Dörfer CE. Animal models for periodontal tissue engineering: a knowledge-generating process. Tissue Eng Part C Methods. 2017;23:900-925.

15. Magan A, Ripamonti U. Biological aspects of periodontal tissue regeneration: cementogenesis and the induction of Sharpey's fibres. SADJ. 2013;68:304-6, 308-12, 314 passim.

16. Huang GT, Sonoyama W, Liu Y, Liu H, Wang S, Shi S. The hidden treasure in apical papilla: the potential role in pulp/dentin regeneration and bioroot engineering. J Endod. 2008;34:645-51.

17. Gong T, Heng BC, Lo EC, Zhang C. Current advance and future prospects of tissue engineering approach to dentin/pulp regenerative therapy. Stem Cells Int. 2016;2016:9204574.

18. Del Fabbro M, Lolato A, Bucchi C, Taschieri S, Weinstein RL. Autologous platelet concentrates for pulp and dentin regeneration: a literature review of animal studies. J Endod. 2016;42:250-7.

19. Onda MJ, Imaizumi M, Tsuchiya S, Morsczeck C. Dental follicle stem cells and tissue engineering. J Oral Sci. 2010;52:541-52.

20. Schulz KF, Altman DG, Moher D; CONSORT Group. CONSORT 2010 statement: updated guidelines for reporting parallel group randomised trials. BMJ. 2010;340:c332.

21. Directive 63/2010/EU of the European Parliament and of the Council of 22 September 2010 on the protection of animals used for scientific purposes (Official Journal of the European Union L 276 of 20/10/2010).

22. Olsson IAS, Silva SPD, Townend D, Sandøe P. Protecting animals and enabling research in the european union: an overview of development and implementation of directive 2010/63/EU. ILAR J. 2016;57:347-357.

23. Vasbinder MA, Locke P. Introduction: global laws, regulations, and standards for animals in research. ILAR J. 2016;57:261-265. 
24. Moher D, Liberati A, Tetzlaff J, Altman DG; PRISMA Group. Preferred reporting items for systematic reviews and meta-analyses: the PRISMA statement. PLoS Med. 2009;6:e1000097.

25. Caballero M, Morse JC, Halevi AE et al. Juvenile swine surgical alveolar cleft model to test novel autologous stem cell therapies. Tissue Eng Part C Methods 2015;21:898908.

26. Konopnicki S, Sharaf B, Resnick C et al. Tissue-engineered bone with 3-dimensionally printed $\beta$-tricalcium phosphate and polycaprolactone scaffolds and early implantation: an in vivo pilot study in a porcine mandible model. J Oral Maxillofac Surg 2015;73:1016.e1-1016.e11.

27. Kuo TF, Lee SY, Wu HD, Poma M, Wu YW, Yang JC. An in vivo swine study for xenografts of calcium sulfate-based bone grafts with human dental pulp stem cells (hDPSCs). Mater Sci Eng C Mater Biol Appl 2015;50:19-23.

28. Bhumiratana S, Bernhard JC, Alfi DM, Yeager K, Eton RE, Bova J, Shah F, Gimble JM, Lopez MJ, Eisig SB, Vunjak-Novakovic G. Tissue-engineered autologous grafts for facial bone reconstruction. Sci Transl Med 2016;8:343ra83.

29. Tee BC, Desai KG, Kennedy KS, Sonnichsen B, Kim DG, Fields HW, Mallery SR, Schwendeman SP, Sun Z. Reconstructing jaw defects with MSCs and PLGAencapsulated growth factors. Am J Transl Res 2016;8:2693-704.

30. Caballero M, Jones DC, Shan Z, Soleimani S, van Aalst JA.Tissue engineering strategies to improve osteogenesis in the juvenile swine alveolar cleft model. Tissue Eng Part C Methods 2017;23:889-899.

31. Cui Y, Lu C, Chen B et al. Restoration of mandibular bone defects with demineralized bone matrix combined with three-dimensional cultured bone marrow-derived mesenchymal stem cells in minipig models. J Mater Sci Mater Med 2018;29:147.

32. Mu S, Tee BC, Emam H, Zhou Y, Sun Z. Culture-expanded mesenchymal stem cell sheets enhance extraction-site alveolar bone growth: An animal study. J Periodontal Res 2018;53:514-524.

33. Bressan E, Botticelli D, Sivolella $S$ et al. Adipose-derived stem cells as a tool for dental implant osseointegration: an experimental study in the dog. Int J Mol Cell Med 2015;4:197-208. 
34. DU C, Yao C, Li N, Wang S, Feng Y, Yang X. Cell sheet-engineered bones used for the reconstruction of mandibular defects in an animal model. Exp Ther Med 2015;10:2216-2220.

35. Huang J, Tian B, Chu F et al. Rapid maxillary expansion in alveolar cleft repaired with a tissue-engineered bone in a canine model. J Mech Behav Biomed Mater 2015;48:8699.

36. Park SY, Kim KH, Gwak EH et al. Ex vivo bone morphogenetic protein 2 gene delivery using periodontal ligament stem cells for enhanced re-osseointegration in the regenerative treatment of peri-implantitis. J Biomed Mater Res A 2015;103:38-47.

37. Alvira-González J, Sánchez-Garcés MÀ, Cairó JR, Del Pozo MR, Sánchez CM, GayEscoda C. Assessment of bone regeneration using adipose-derived stem cells in critical-size alveolar ridge defects: an experimental study in a dog model. Int J Oral Maxillofac Implants 2016;31:196-203.

38. Wang F, Li Q, Wang Z. A comparative study of the effect of Bio-Oss ${ }^{\circledR}$ in combination with concentrated growth factors or bone marrow-derived mesenchymal stem cells in canine sinus grafting. J Oral Pathol Med 2017;46:528-536.

39. Xu L, Zhang W, Lv K, Yu W, Jiang X, Zhang F. Peri-Implant Bone Regeneration Using rhPDGF-BB, BMSCs, and $\beta$-TCP in a canine model. Clin Implant Dent Relat Res 2016;18:241-52.

40. Xu L, Sun X, Bai J et al. Reosseointegration following regenerative therapy of tissueengineered bone in a canine model of experimental peri-implantitis. Clin Implant Dent Relat Res 2016;18:379-91.

41. Zeng JJ, Guo P, Zhou N, Xie QT, Liao FC. Treatment of large bone defects with a novel biological transport disc in non-vascular transport distraction osteogenesis. Int J Oral Maxillofac Surg 2016;45:670-7.

42. Khojasteh A, Fahimipour F, Jafarian $M$ et al. Bone engineering in dog mandible: Coculturing mesenchymal stem cells with endothelial progenitor cells in a composite scaffold containing vascular endothelial growth factor. J Biomed Mater Res B Appl Biomater 2017;105:1767-1777. 
43. Sánchez-Garcés MÀ, Alvira-González J, Sánchez CM, Barbany Cairó JR, Del Pozo MR, Gay-Escoda C. Bone regeneration using adipose-derived stem cells with fibronectin in dehiscence-type defects associated with dental implants: an experimental study in a dog model. Int J Oral Maxillofac Implants 2017;32:e97-e106.

44. Shafieian R, Matin MM, Rahpeyma A et al. Effects of human adipose-derived stem cells and platelet-rich plasma on healing response of canine alveolar surgical bone defects. Arch Bone Jt Surg 2017;5:406-418.

45. Wang F, Zhou Y, Zhou J et al. Comparison of intraoral bone regeneration with iliac and alveolar BMSCs. J Dent Res 2018;97:1229-1235.

46. Washio $K$, Tsutsumi $Y$, Tsumanuma $Y$ et al. In vivo periodontium formation around titanium implants using periodontal ligament cell sheet. Tissue Eng Part A 2018;24:1273-1282.

47. Ardjomandi N, Duttenhoefer F, Xavier S, Oshima T, Kuenz A, Sauerbier S. In vivo comparison of hard tissue regeneration with ovine mesenchymal stem cells processed with either the FICOLL method or the BMAC method. J Craniomaxillofac Surg 2015;43:1177-83.

48. Gallego L, Pérez-Basterrechea M, García-Consuegra L et al. Repair of segmental mandibular bone defects in sheep using bone marrow stromal cells and autologous serum scaffold: a pilot study. J Clin Periodontol 2015;42:1143-51.

49. Cao Y, Liu Z, Xie $Y$ et al. Adenovirus-mediated transfer of hepatocyte growth factor gene to human dental pulp stem cells under good manufacturing practice improves their potential for periodontal regeneration in swine. Stem Cell Res Ther 2015;6:249.

50. Fawzy El-Sayed KM, Mekhemar MK, Beck-Broichsitter BE et al. Periodontal regeneration employing gingival margin-derived stem/progenitor cells in conjunction with IL-1ra-hydrogel synthetic extracellular matrix. J Clin Periodontol 2015;42:448-57.

51. Liu D, Wang Y, Jia Z et al. Demethylation of IGFBP5 by histone demethylase KDM6B promotes mesenchymal stem cell-mediated periodontal tissue regeneration by enhancing osteogenic differentiation and anti-inflammation potentials. Stem Cells 2015;33:2523-36. 
52. Hu J, Cao Y, Xie Y et al. Periodontal regeneration in swine after cell injection and cell sheet transplantation of human dental pulp stem cells following good manufacturing practice. Stem Cell Res Ther 2016;7:130.

53. Basan $T$, Welly $D$, Kriebel $K$ et al. Enhanced periodontal regeneration using collagen, stem cells or growth factors. Front Biosci (Schol Ed) 2017;9:180-193.

54. Li G, Han N, Zhang X et al. Local injection of allogeneic stem cells from apical papilla enhanced periodontal tissue regeneration in minipig model of periodontitis. Biomed Res Int 2018;2018:3960798.

55. Li G, Han N, Yang $H$ et al. SFRP2 promotes stem cells from apical papilla-mediated periodontal tissue regeneration in miniature pig. J Oral Rehabil 2020;47 Suppl 1:1218.

56. Venkataiah VS, Handa K, Njuguna MM et al. Periodontal regeneration by allogeneic transplantation of adipose tissue derived multi-lineage progenitor stem cells in vivo. Sci Rep 2019;9:921.

57. Lee JS, Kim HS, Park SY et al. Synergistic effects of a calcium phosphate/fibronectin coating on the adhesion of periodontal ligament stem cells onto decellularized dental root surfaces. Cell Transplant 2015;24:1767-79.

58. Nagahara T, Yoshimatsu S, Shiba $H$ et al. Introduction of a mixture of $\beta$-tricalcium phosphate into a complex of bone marrow mesenchymal stem cells and type I collagen can augment the volume of alveolar bone without impairing cementum regeneration. J Periodontol 2015;86:456-64.

59. Liu Z, Yin $X$, Ye $Q$ et al. Periodontal regeneration with stem cells-seeded collagenhydroxyapatite scaffold. J Biomater Appl 2016;31:121-31.

60. Luo J, Xu J, Cai J, Wang L, Sun Q, Yang P. The in vitro and in vivo osteogenic capability of the extraction socket-derived early healing tissue. J Periodontol 2016;87:1057-66.

61. Zhu M, Miao B, Zhu J, Wang H, Zhou Z. Transplantation of periodontal ligament cell sheets expressing human $\beta$-defensin-3 promotes anti-inflammation in a canine model of periodontitis. Mol Med Rep 2017;16:7459-7467.

62. Shi $H$, Zong $W, X u X$, Chen J. Improved biphasic calcium phosphate combined with periodontal ligament stem cells may serve as a promising method for periodontal regeneration. Am J Transl Res 2018;10:4030-4041. 
63. Rezaei M, Jamshidi S, Saffarpour A et al. Transplantation of bone marrow-derived mesenchymal stem cells, platelet-rich plasma, and fibrin glue for periodontal regeneration. Int J Periodontics Restorative Dent 2019;39:e32-e45.

64. Zhou Q, Gu X, Dong J et al. The use of TLR2 modified BMSCs for enhanced bone regeneration in the inflammatory micro-environment. Artif Cells Nanomed Biotechnol 2019;47:3329-3337.

65. Vaquette C, Saifzadeh S, Farag A, Hutmacher DW, Ivanovski S. Periodontal Tissue Engineering with a Multiphasic Construct and Cell Sheets. J Dent Res 2019;98:673681.

66. Mangione F, EzEldeen M, Bardet $C$ et al. Implanted dental pulp cells fail to induce regeneration in partial pulpotomies. J Dent Res 2017;96:1406-1413.

67. Zhu X, Liu J, Yu Z et al. A miniature swine model for stem cell-based de novo regeneration of dental pulp and dentin-like tissue. Tissue Eng Part C Methods 2018;24:108-120.

68. Chen YJ, Zhao YH, Zhao YJ et al. Potential dental pulp revascularization and odonto/osteogenic capacity of a novel transplant combined with dental pulp stem cells and platelet-rich fibrin. Cell Tissue Res 2015;361:439-55.

69. Murakami M, Hayashi Y, lohara K, Osako Y, Hirose Y, Nakashima M. Trophic effects and regenerative potential of mobilized mesenchymal stem cells from bone marrow and adipose tissue as alternative cell sources for pulp/dentin regeneration. Cell Transplant 2015;24:1753-65.

70. lohara K, Fujita M, Ariji Y et al. Assessment of pulp regeneration induced by stem cell therapy by magnetic resonance imaging. J Endod 2016;42:397-401.

71. Jia W, Zhao Y, Yang J, Wang W, Wang X, Ling L, Ge L. Simvastatin promotes dental pulp stem cell-induced coronal pulp regeneration in pulpotomized teeth. J Endod 2016;42:1049-54.

72. Bakhtiar $H$, Mirzaei $H$, Bagheri $M R$ et al. Histologic tissue response to furcation perforation repair using mineral trioxide aggregate or dental pulp stem cells loaded onto treated dentin matrix or tricalcium phosphate. Clin Oral Investig 2017;21:15791588. 
73. El Ashiry EA, Alamoudi NM, El Ashiry MK, Bastawy HA, El Derwi DA, Atta HM. Tissue engineering of necrotic dental pulp of immature teeth with apical periodontitis in dogs: radiographic and histological evaluation. J Clin Pediatr Dent 2018;42:373-382.

74. lohara K, Utsunomiya S, Kohara S, Nakashima M. Allogeneic transplantation of mobilized dental pulp stem cells with the mismatched dog leukocyte antigen type is safe and efficacious for total pulp regeneration. Stem Cell Res Ther 2018;9:116.

75. El-Zekrid MH, Mahmoud SH, Ali FA, Helal ME, Grawish ME. Healing capacity of autologous bone marrow-derived mesenchymal stem cells on partially pulpotomized dogs' teeth. J Endod 2019;45:287-294.

76. Chen G, Chen J, Yang B et al. Combination of aligned PLGA/Gelatin electrospun sheets, native dental pulp extracellular matrix and treated dentin matrix as substrates for tooth root regeneration. Biomaterials 2015;52:56-70.

77. Luo X, Yang B, Sheng $L$ et al. CAD based design sensitivity analysis and shape optimization of scaffolds for bio-root regeneration in swine. Biomaterials 2015;57:5972.

78. Gao ZH, Hu L, Liu GL et al. Bio-Root and implant-based restoration as a tooth replacement alternative. J Dent Res 2016;95:642-9.

79. Yang KC, Kitamura Y, Wu CC, Chang HH, Ling TY, Kuo TF. Tooth germ-like construct transplantation for whole-tooth regeneration: an in vivo study in the miniature pig. Artif Organs 2016;40:E39-50.

80. Zhang W, Vazquez B, Oreadi D, Yelick PC. Decellularized tooth bud scaffolds for tooth regeneration. J Dent Res 2017;96:516-523.

81. Wu Z, Wang F, Fan Z et al. Whole-tooth regeneration by allogeneic cell reassociation in pig jawbone. Tissue Eng Part A 2019;25:1202-1212.

82. Ono $M$, Oshima $M$, Ogawa $M$ et al. Practical whole-tooth restoration utilizing autologous bioengineered tooth germ transplantation in a postnatal canine model. Sci Rep 2017;7:44522.

83. Zhang Z. Bone regeneration by stem cell and tissue engineering in oral and maxillofacial region. Front Med. 2011;5:401-13. 
84. Gorin C, Rochefort GY, Bascetin R et al. Priming dental pulp stem cells with fibroblast growth factor- 2 increases angiogenesis of implanted tissue-engineered constructs through hepatocyte growth factor and vascular endothelial growth factor secretion. Stem Cells Transl Med 2016;5:392-404.

85. Devlin H. Early bone healing events following rat molar tooth extraction. Cells Tissues Organs. 2000;167:33-7.

86. Abukawa H, Shin M, Williams WB, Vacanti JP, Kaban LB, Troulis MJ. Reconstruction of mandibular defects with autologous tissue-engineered bone. J Oral Maxillofac Surg. 2004;62:601-6.

87. Abukawa H, Zhang W, Young CS et al. Reconstructing mandibular defects using autologous tissue-engineered tooth and bone constructs. J Oral Maxillofac Surg. 2009;67:335-47.

88. Zheng $Y$, Liu $Y$, Zhang CM, Zhang HY, Li WH, Shi S, Le AD, Wang SL. Stem cells from deciduous tooth repair mandibular defect in swine. J Dent Res. 2009;88:249-54.

89. Donos N, Park JC, Vajgel A, de Carvalho Farias B, Dereka X. Description of the periodontal pocket in preclinical models: limitations and considerations. Periodontol 2000 2018;76:16-34.

90. Ribitsch I, Baptista PM, Lange-Consiglio A et al. Large animal models in regenerative medicine and tissue engineering: to do or not to do. Front Bioeng Biotechnol. 2020;8:972.

91. Valbonetti L, Berardinelli P, Scarano A et al. Translational value of sheep as animal model to study sinus augmentation. J Craniofac Surg. 2015;26:737-40.

92. Altaii M, Broberg M, Cathro P, Richards L. Standardisation of sheep model for endodontic regeneration/revitalisation research. Arch Oral Biol 2016;65:87-94.

93. Ackermans NL, Martin LF, Codron D et al. Confirmation of a wear-compensation mechanism in dental roots of ruminants. Anat Rec (Hoboken) 2020.

94. Diogenes A, Hargreaves KM. Microbial modulation of stem cells and future directions in regenerative endodontics. J Endod 2017;43:S95-S101.

95. Nakashima M, lohara K, Bottino MC, Fouad AF, Nör JE, Huang GT. Animal models for stem cell-based pulp regeneration: foundation for human clinical applications. Tissue Eng Part B Rev 2019;25:100-113. 
96. Nakashima M, lohara K, Murakami M, Nakamura H, Sato Y, Ariji Y, Matsushita K. Pulp regeneration by transplantation of dental pulp stem cells in pulpitis: a pilot clinical study. Stem Cell Res Ther. 2017;8:61.

97. Yoneda N, Noiri Y, Matsui S, Kuremoto K, Maezono H, Ishimoto T, Nakano T, Ebisu S, Hayashi M. Development of a root canal treatment model in the rat. Sci Rep. $2017 ; 7: 3315$.

98. Nakatomi M, Quispe-Salcedo A, Sakaguchi M, Ida-Yonemochi H, Okano H, Ohshima H. Nestin expression is differently regulated between odontoblasts and the subodontoblastic layer in mice. Histochem Cell Biol. 2018;149:383-391.

99. Iohara K, Zheng L, Ito $\mathrm{M}$ et al. Regeneration of dental pulp after pulpotomy by transplantation of CD31(-)/CD146(-) side population cells from a canine tooth. Regen Med. 2009;4:377-85.

100. Iohara K, Imabayashi K, Ishizaka R et al. Complete pulp regeneration after pulpectomy by transplantation of CD105+ stem cells with stromal cell-derived factor-1. Tissue Eng Part A. 2011;17:1911-20.

101. Iohara K, Murakami $\mathrm{M}$, Takeuchi $\mathrm{N}$ et al. A novel combinatorial therapy with pulp stem cells and granulocyte colony-stimulating factor for total pulp regeneration. Stem Cells Transl Med. 2013;2:521-33.

102. Zheng $Y$, Wang $X Y$, Wang $Y M$, Liu $X Y$, Zhang CM, Hou BX, Wang SL. Dentin regeneration using deciduous pulp stem/progenitor cells. J Dent Res. 2012;91:676-82.

103. Otsu K, Kumakami-Sakano M, Fujiwara $N$ et al. Stem cell sources for tooth regeneration: current status and future prospects. Front Physiol 2014;5:36.

104. Oshima M, Tsuji T. Whole tooth regeneration as a future dental treatment. Adv Exp Med Biol. 2015;881:255-69.

105. Sonoyama W, Liu Y, Fang D et al. Mesenchymal stem cell-mediated functional tooth regeneration in swine. PLoS One. 2006;1:e79.

106. Zhang W, Abukawa H, Troulis MJ, Kaban LB, Vacanti JP, Yelick PC. Tissue engineered hybrid tooth-bone constructs. Methods. 2009;47:122-8.

107. Yamamoto-Fukud T, Shibata $Y$, Hishikawa $Y$ et al. Effects of various decalcification protocols on detection of DNA strand breaks by terminal dUTP nick end labelling. Histochem J 2000;32:697-702. 
Figures legends

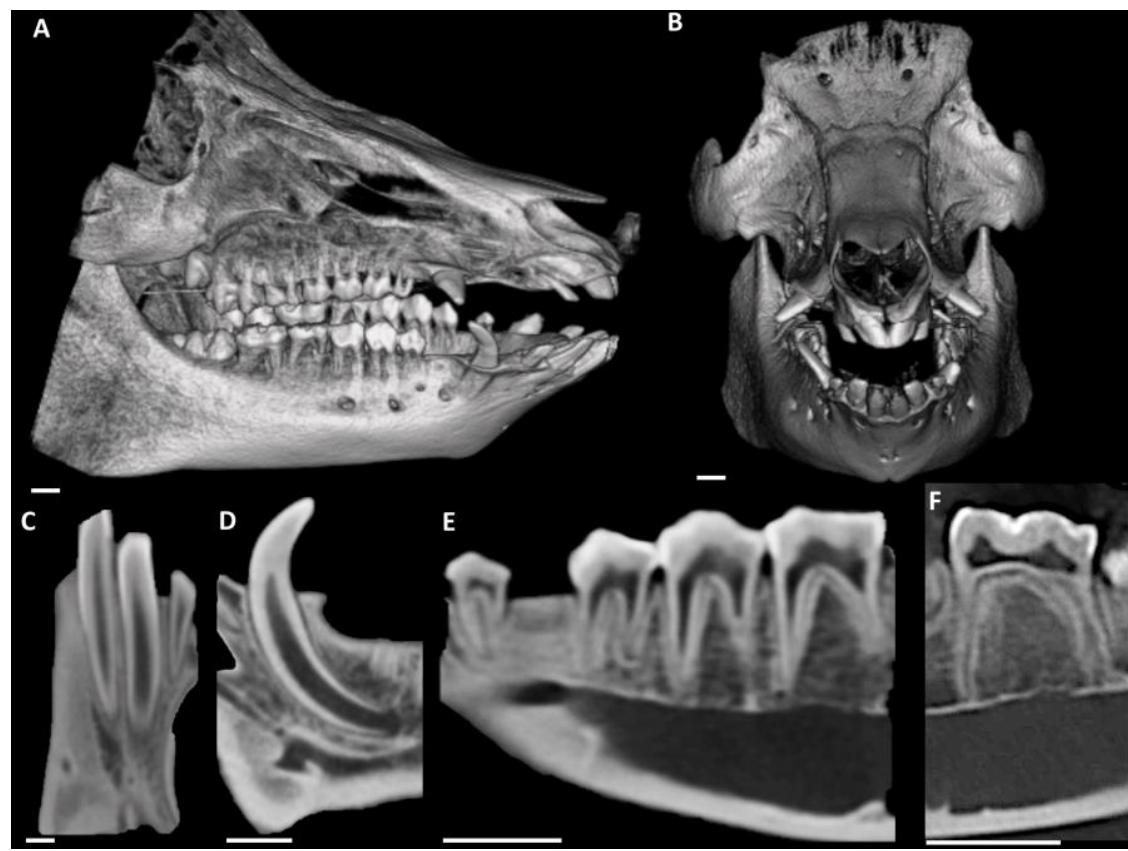

Figure 1. Pig anatomy- Cone Beam CT. A) Skull: lateral view. B) Skull: frontal view. C) Lower incisor region. D) Lower canine. E) Lower premolars region. F) Lower molar anatomy.

Scale bar: $1 \mathrm{~cm}$. 


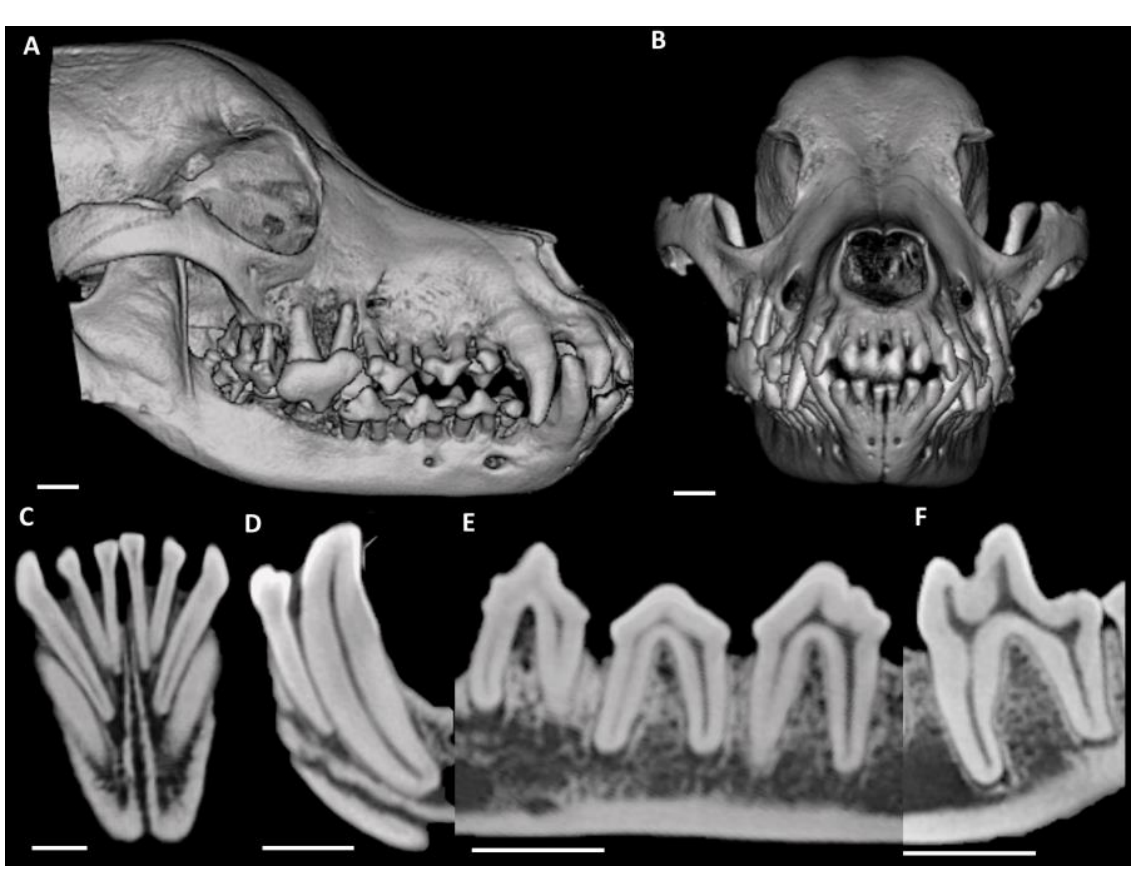

Figure 2. Dog anatomy- Cone Beam CT. A) Skull: lateral view. B) Skull: frontal view. C) Lower incisor region. D) Lower canine. E) Lower premolars region. F) Lower molar anatomy.

Scale bar: $1 \mathrm{~cm}$. 


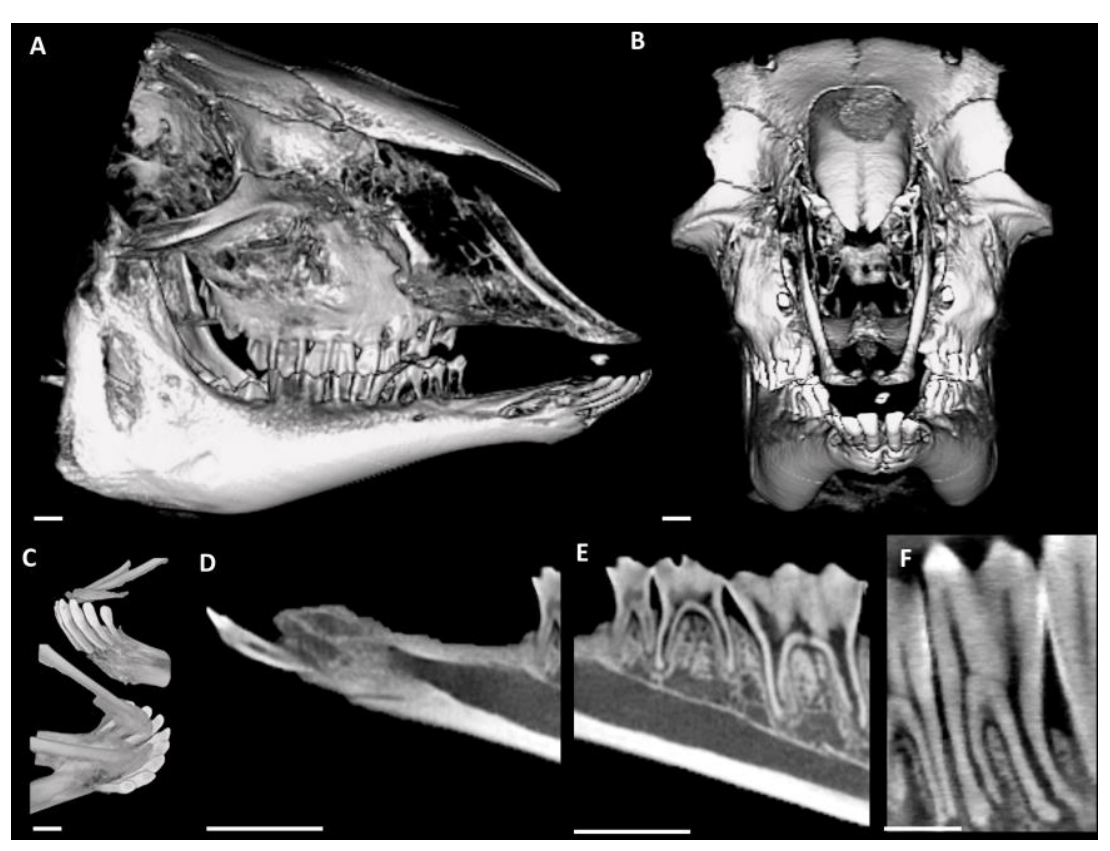

Figure 3. Sheep anatomy- Cone Beam CT. A) Skull: lateral view. B) Skull: frontal view. C) Upper jaw dental pad and lower incisor regions. D) Diastema (absence of the canine between incisors and premolars). E) Lower premolars region. F) Lower molar anatomy.

Scale bar: $1 \mathrm{~cm}$. 
Page 36 of 54

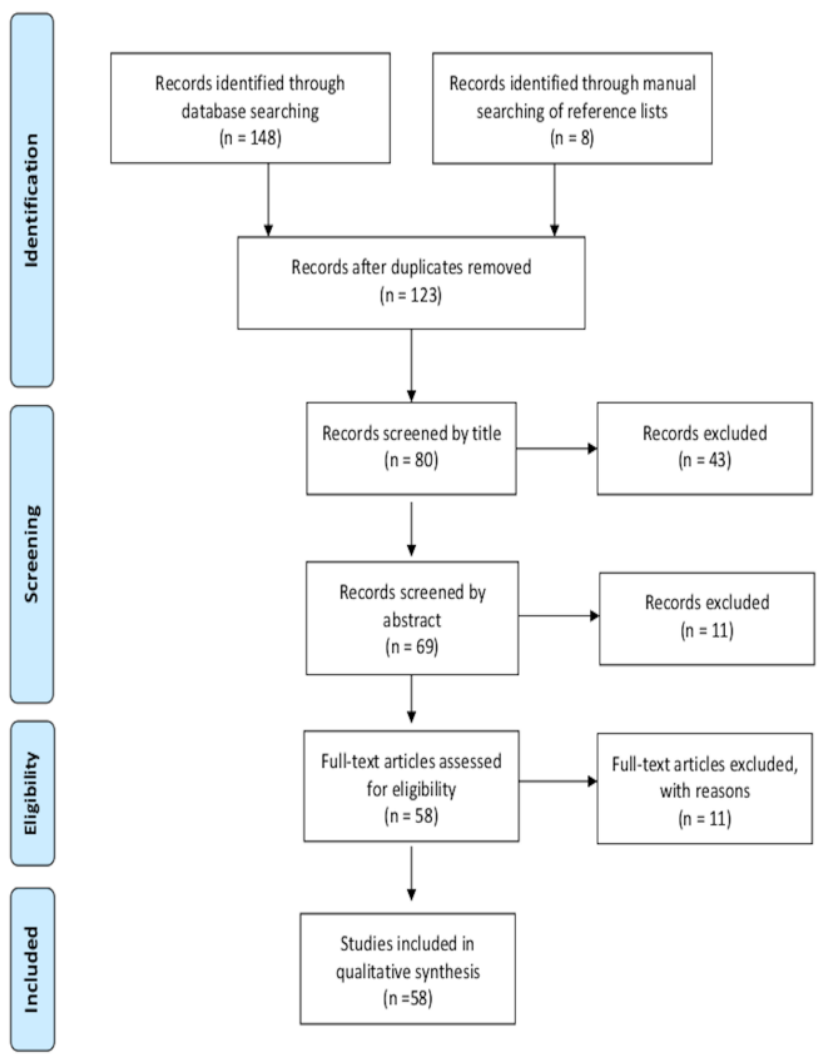

Figure 4. Flowchart of the manuscript selection process. 


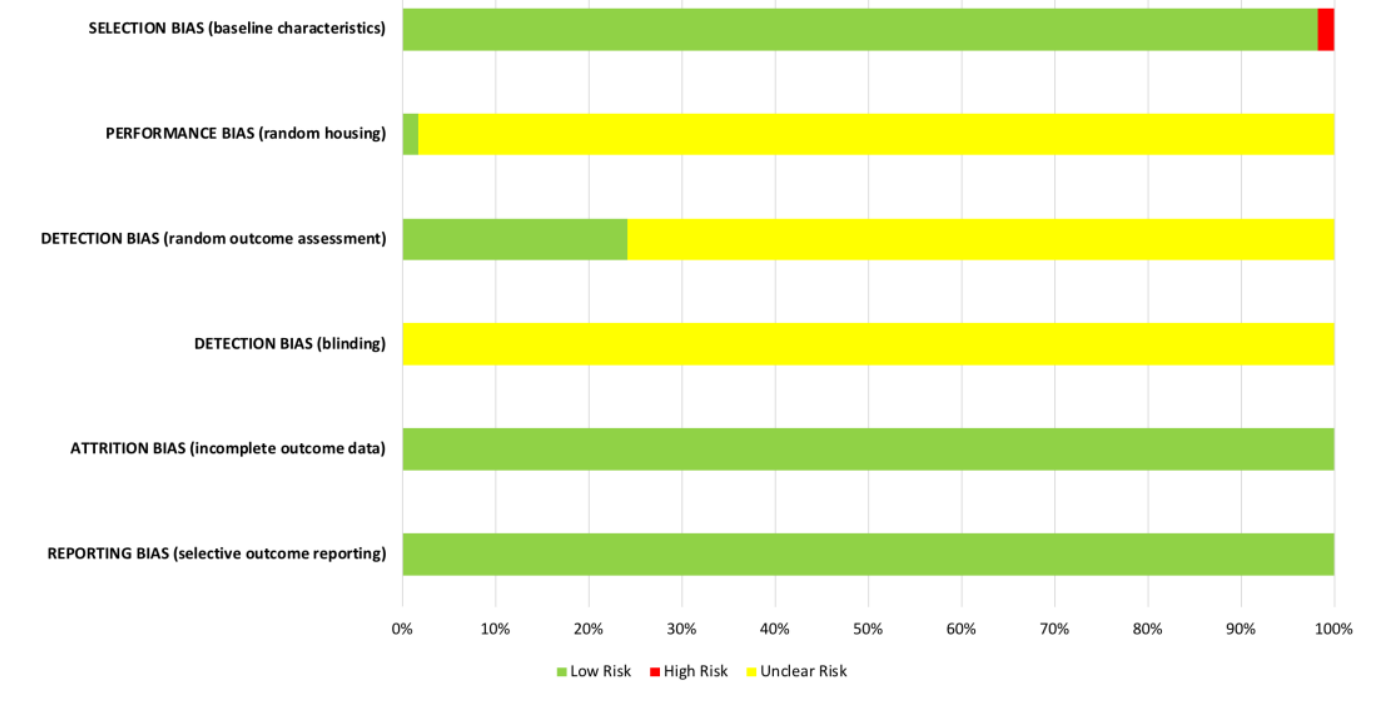

Figure 5. Risk of bias assessment evaluated according to the SYstematic Review Centre for Laboratory animal Experimentation (SYRCLE). Selection bias: baseline characteristics. Performance bias: random housing. Detection bias: random outcome assessment; blinding. Attrition bias: incomplete outcome data. Reporting bias: selective outcome reporting. 
Table 1. Characteristics of the large animal models.

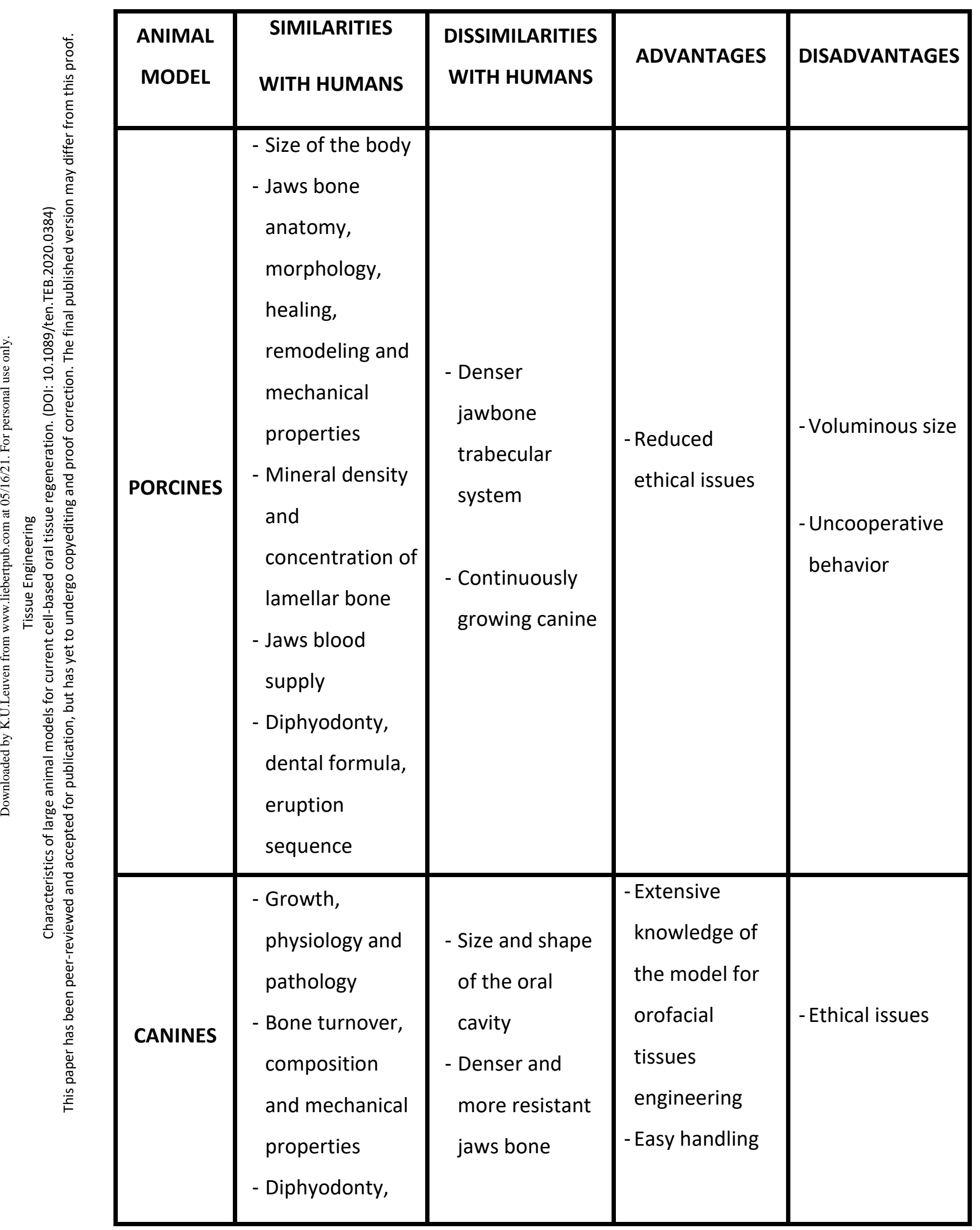




\begin{tabular}{|c|c|c|c|c|}
\hline & $\begin{array}{l}\text { dental anatomy, } \\
\text { dental formula }\end{array}$ & & & \\
\hline OVINES & $\begin{array}{l}\text { - Size of the body } \\
\text { - Diphyodonty, } \\
\text { dental formula } \\
\text { and shape of } \\
\text { permanent } \\
\text { teeth }\end{array}$ & $\begin{array}{l}\text { - Ruminant } \\
\text { digestion } \\
\text { - pH of saliva } \\
\text { - Absence of } \\
\text { upper incisors, } \\
\text { upper and } \\
\text { lower canines } \\
\text { - Jawbone } \\
\text { density and } \\
\text { biomechanical } \\
\text { properties } \\
\text { - Age related } \\
\text { bone structure } \\
\text { and remodeling }\end{array}$ & $\begin{array}{l} \\
\text { - Reduced } \\
\text { ethical issues } \\
\text { - Extensive } \\
\text { availability } \\
\text { - Easy handling } \\
\text { - Less expensive } \\
\text { housing }\end{array}$ & $\begin{array}{l} \\
\text { - Lack of } \\
\text { literature } \\
\text { - Limits of } \\
\text { comparisons } \\
\text { between } \\
\text { studies using } \\
\text { different ages } \\
\text { animals }\end{array}$ \\
\hline
\end{tabular}


Table 2. Bone regeneration.

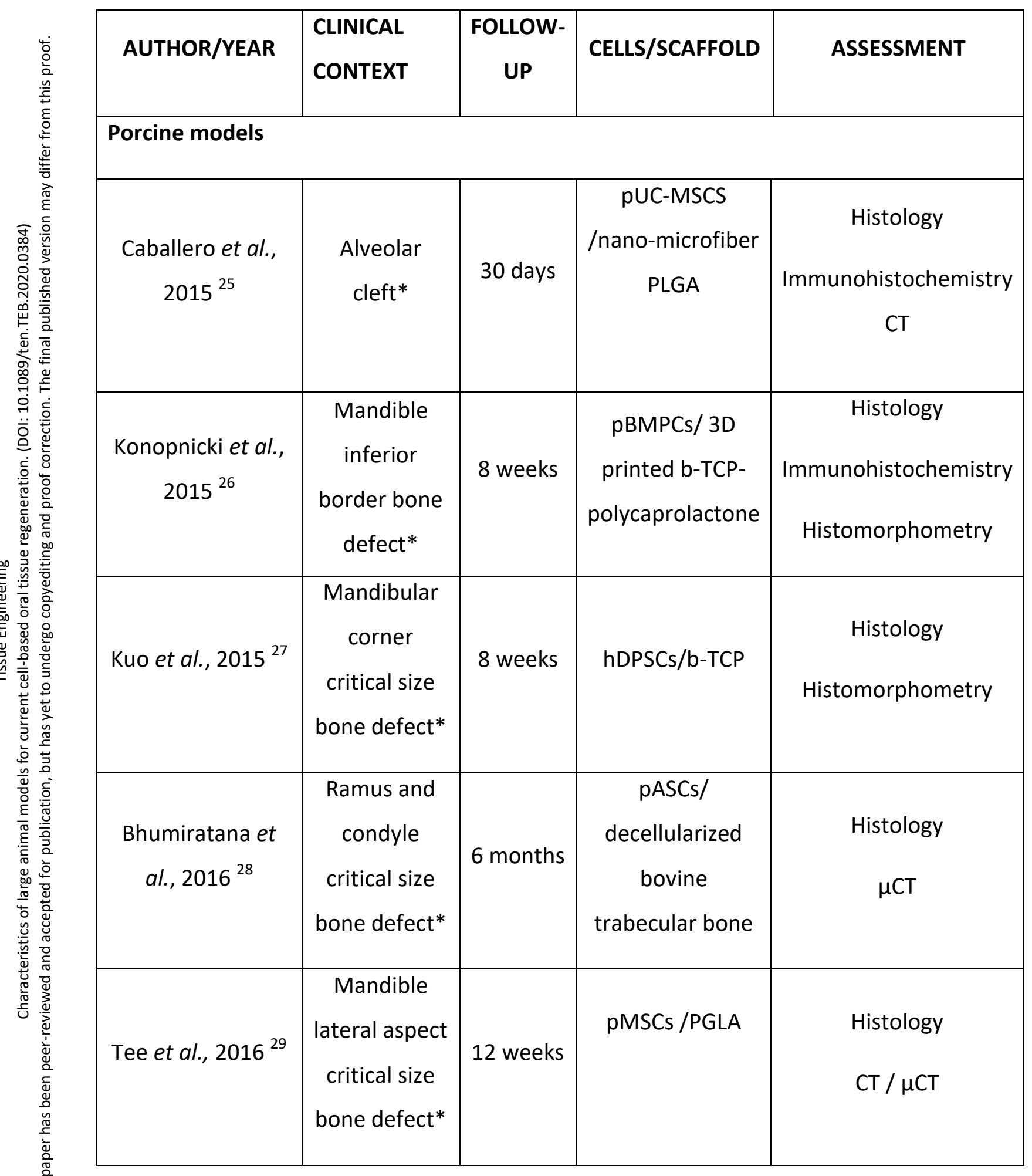


41

\begin{tabular}{|c|c|c|c|c|c|}
\hline 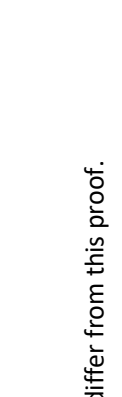 & $\begin{array}{c}\text { Caballero et al., } \\
2017^{30}\end{array}$ & $\begin{array}{c}\text { Alveolar } \\
\text { cleft* }\end{array}$ & 90 Days & $\begin{array}{c}\text { pUC-MSCS } \\
\text { /nano-microfiber } \\
\text { PLGA }\end{array}$ & $\begin{array}{c}\text { Histology } \\
\text { Immunohistochemistry } \\
\text { CT } \\
\text { Mechanical tests }\end{array}$ \\
\hline 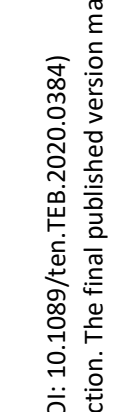 & Cui et al., $2018^{31}$ & $\begin{array}{c}\text { Mandible } \\
\text { inferior } \\
\text { border } \\
\text { critical size } \\
\text { bone defect* }\end{array}$ & 4 weeks & pBMSCs/DBM & $\begin{array}{l}\text { Histology } \\
\qquad \mathrm{CT}\end{array}$ \\
\hline 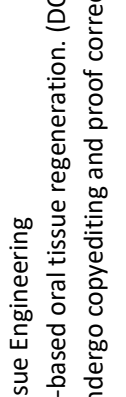 & Mu et al., $2018^{32}$ & $\begin{array}{l}\text { Mandible } \\
\text { extraction } \\
\text { socket }\end{array}$ & 6 weeks & pMCSs sheets & $\begin{array}{l}\text { Histology } \\
\text { Florescence } \\
\text { microscopy } \\
\text { Histomorphometry }\end{array}$ \\
\hline 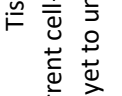 & \multicolumn{5}{|l|}{ Canine models } \\
\hline 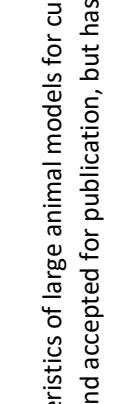 & $\begin{array}{c}\text { Bressan et al., } \\
2015^{33}\end{array}$ & $\begin{array}{l}\text { Mandible } \\
\text { premolar- } \\
\text { molar region } \\
\text { peri-implant } \\
\text { bone defect* }\end{array}$ & 4 weeks & hADCs / HA-TCP & $\begin{array}{l}\text { Histology } \\
\text { Histomorphometry }\end{array}$ \\
\hline 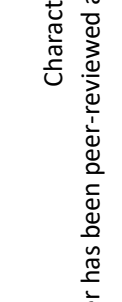 & Du et al., $2015^{34}$ & $\begin{array}{l}\text { Mandible } \\
\text { body bone } \\
\text { defect* }\end{array}$ & 16 weeks & cBMSCs/ PLGA & $\begin{array}{l}\text { Histology } \\
\text { Histomorphometry } \\
\text { Mechanical analysis }\end{array}$ \\
\hline $\begin{array}{l}\frac{0}{0} \\
\frac{0}{0} \\
\frac{0}{E} \\
F\end{array}$ & $\begin{array}{l}\text { Huang et al., } 2015 \\
35\end{array}$ & $\begin{array}{l}\text { Alveolar } \\
\text { cleft* }\end{array}$ & 12 weeks & cBMSCs/b-TCP & $\begin{array}{c}\text { Histology } \\
\text { Histomorphometry }\end{array}$ \\
\hline
\end{tabular}


42

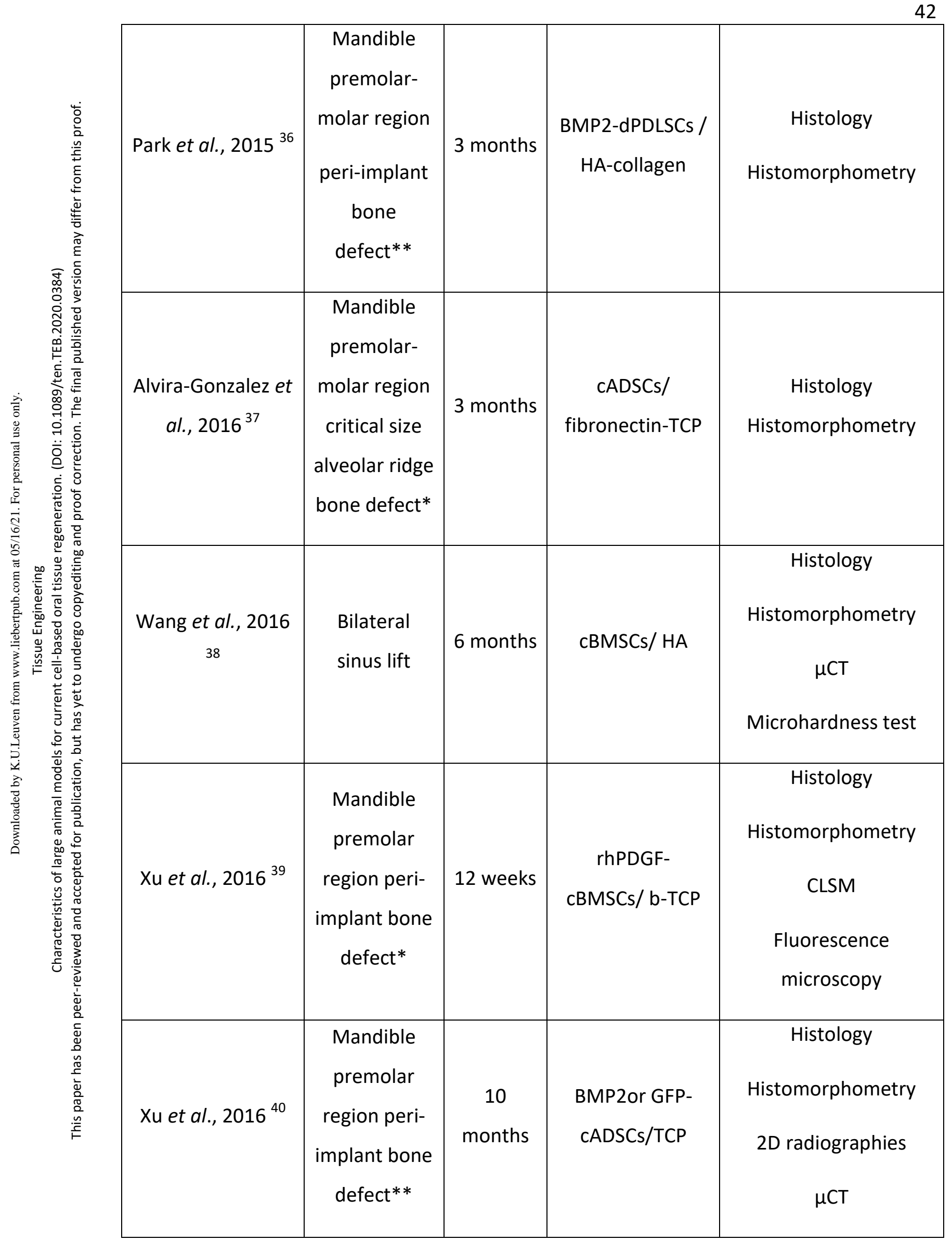




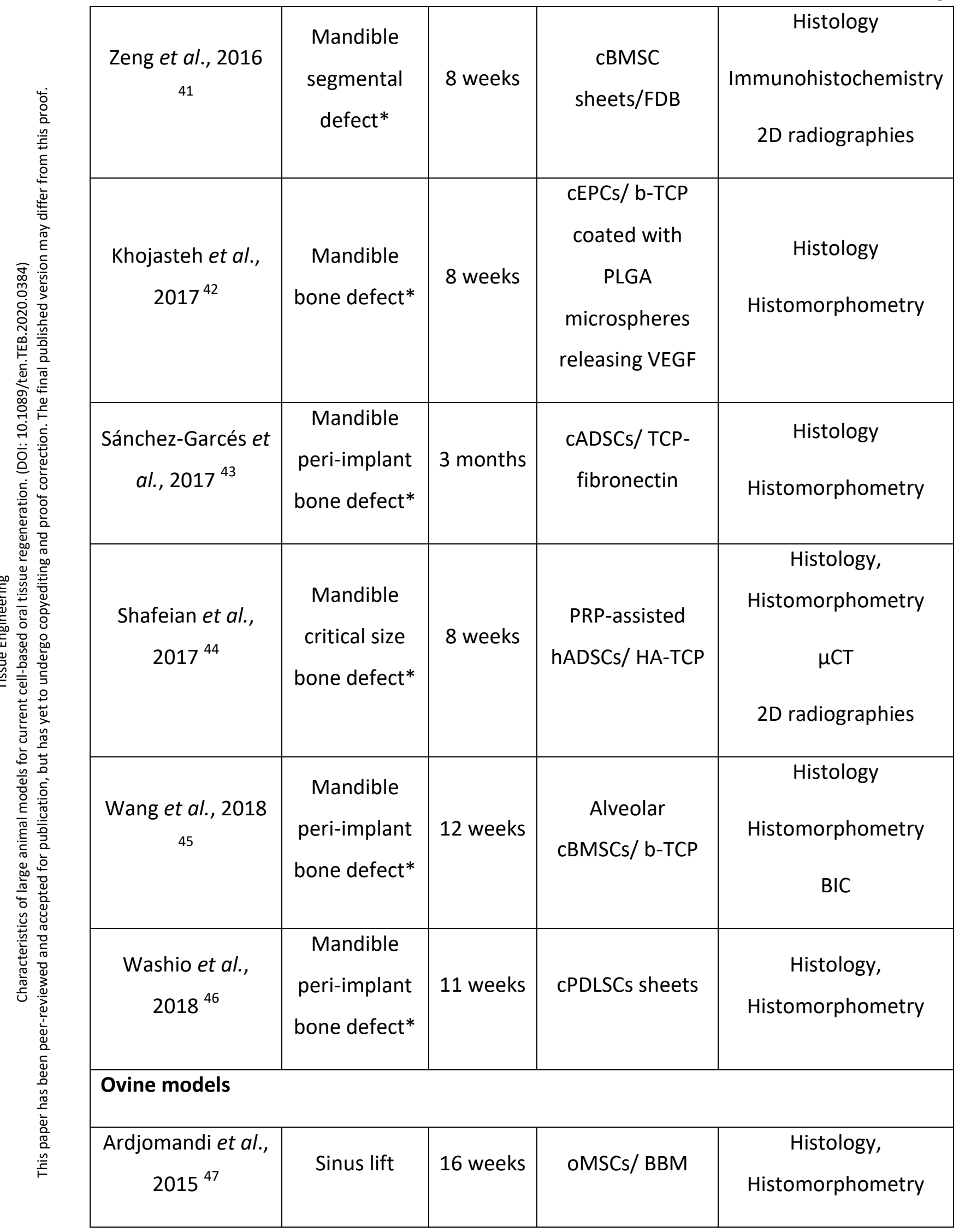




\section{4}

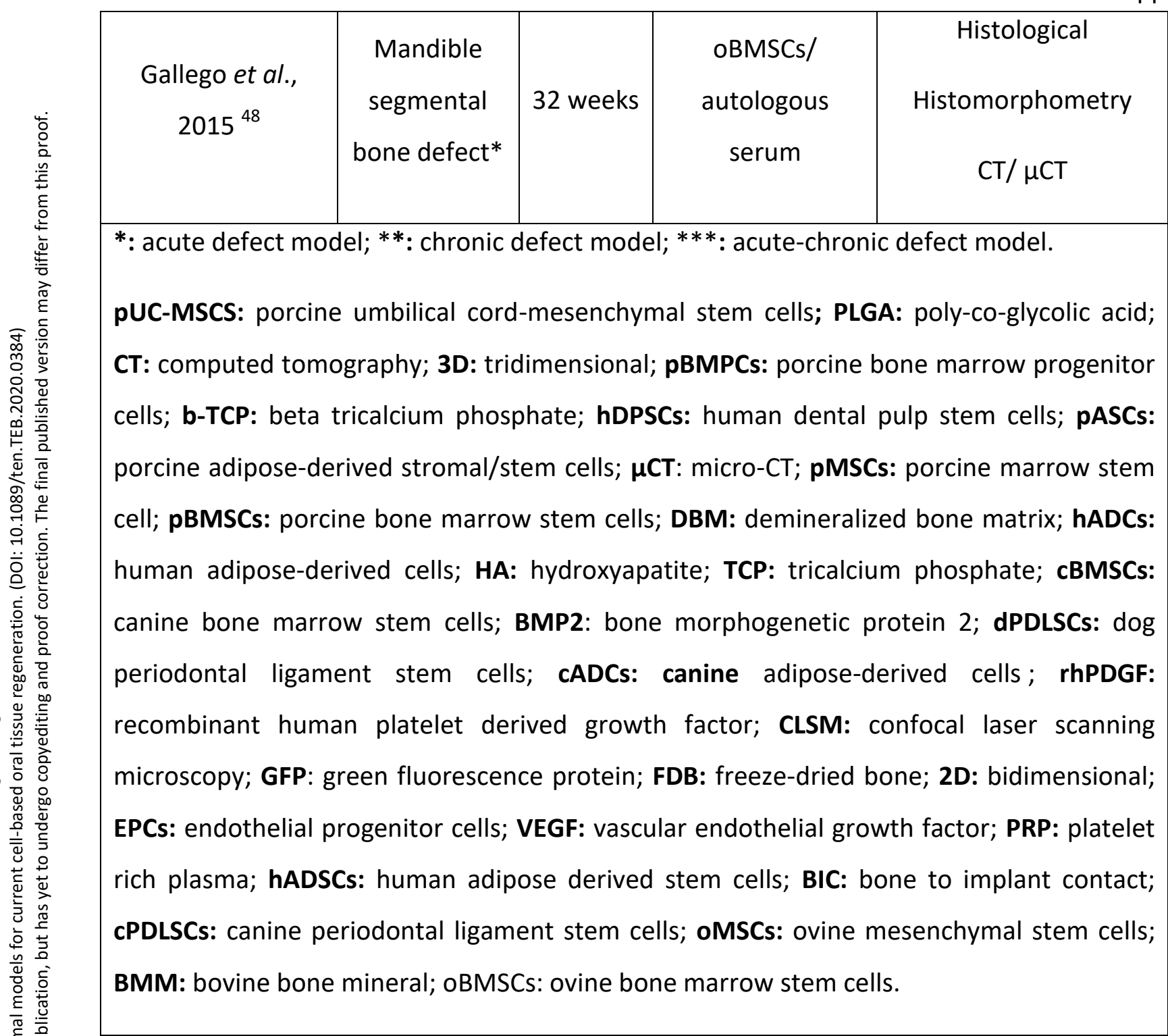


Table 3. Periodontium regeneration.

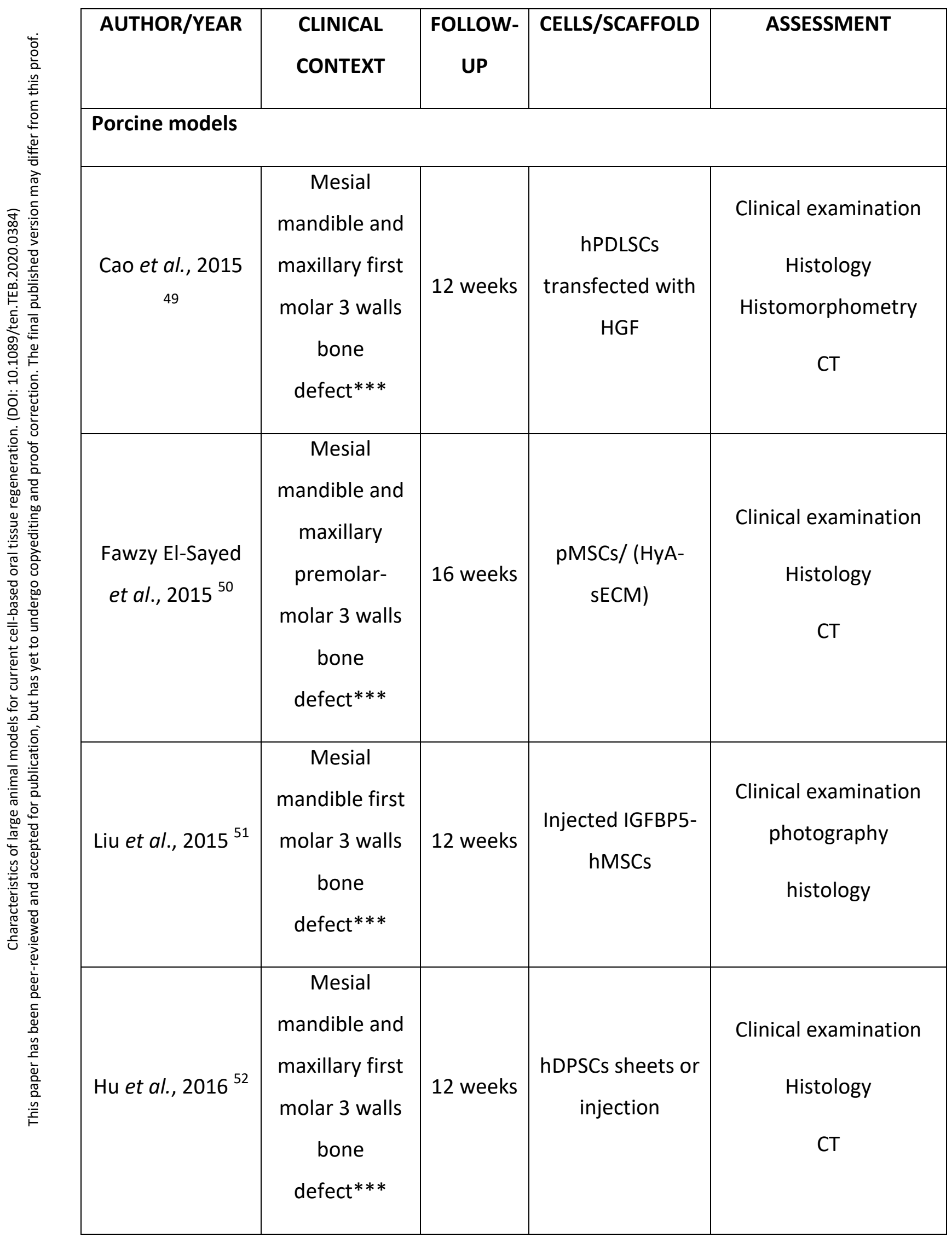


46

\begin{tabular}{|c|c|c|c|c|c|}
\hline 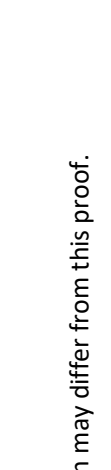 & $\begin{array}{c}\text { Basan et al., } \\
2017^{53}\end{array}$ & $\begin{array}{l}\text { Mandible third } \\
\text { premolar and } \\
\text { first molar } \\
\text { class II } \\
\text { furcation } \\
\text { defect* }\end{array}$ & 120 days & $\begin{array}{l}\text { pPDLSCs/ } \\
\text { collagen }\end{array}$ & $\begin{array}{l}\text { Histology } \\
\text { Fluorescence } \\
\text { microscopy } \\
\text { Histomorphometry }\end{array}$ \\
\hline 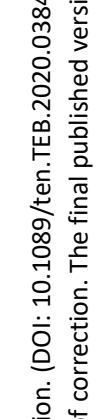 & Li et al., $2018^{54}$ & $\begin{array}{c}\text { Mesial } \\
\text { mandible first } \\
\text { molar } 3 \text { walls } \\
\text { bone } \\
\text { defect*** }\end{array}$ & 12 weeks & hSCAPs & $\begin{array}{l}\text { Clinical examination } \\
\text { Histology } \\
\text { Histomorphometry } \\
\text { CT }\end{array}$ \\
\hline 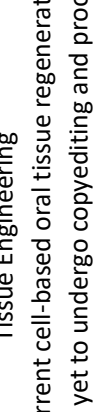 & Li et al., $2019^{55}$ & $\begin{array}{c}\text { Mesial } \\
\text { mandible first } \\
\text { molar } 3 \text { walls } \\
\text { bone } \\
\text { defect*** }\end{array}$ & 12 weeks & SFRP2-hSCAPS & $\begin{array}{c}\text { Clinical examination } \\
\text { Histology } \\
\text { Histomorphometry } \\
\text { CT }\end{array}$ \\
\hline 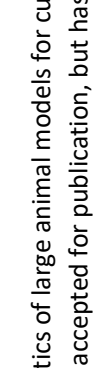 & $\begin{array}{l}\text { Venkataiah et } \\
\text { al., } 2019^{56}\end{array}$ & $\begin{array}{l}\text { Mandible } \\
\text { premolars } \\
\text { class II } \\
\text { furcation } \\
\text { defect* }\end{array}$ & 4 weeks & $\begin{array}{l}\text { pADMPC/ fibrin } \\
\text { gel complex }\end{array}$ & $\begin{array}{c}\text { Histology } \\
\text { Histomorphometry } \\
\mu \mathrm{CT}\end{array}$ \\
\hline 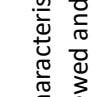 & \multicolumn{5}{|l|}{ Canine models } \\
\hline 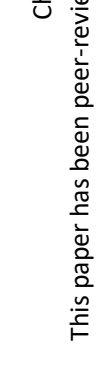 & $\begin{array}{l}\text { Lee et al., } 2015 \\
57\end{array}$ & $\begin{array}{c}\text { Tooth } \\
\text { reimplantation } \\
\text { onto maxillary } \\
\text { extraction } \\
\text { socket }\end{array}$ & 8 weeks & $\begin{array}{c}\text { cPDLSCs/ } \\
\text { decellularized } \\
\text { dental root + } \\
\text { (CaP)-fibronectin } \\
\text { coating }\end{array}$ & $\begin{array}{l}\text { Histology } \\
\text { } \mu \mathrm{CT}\end{array}$ \\
\hline & Nagahara et al., & Mandible first, & 8 weeks & cBMMSC/ & Histology \\
\hline
\end{tabular}


47

\begin{tabular}{|c|c|c|c|c|c|}
\hline 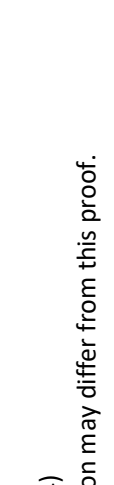 & $2015^{58}$ & $\begin{array}{l}\text { second and } \\
\text { third } \\
\text { premolars } \\
\text { class III } \\
\text { furcation } \\
\text { defect*** }\end{array}$ & & $\begin{array}{c}\text { atelocollagen-b- } \\
\text { TCP }\end{array}$ & $\begin{array}{c}\text { Immunohistochemistry } \\
\text { TRAP } \\
\text { Histomorphometry }\end{array}$ \\
\hline 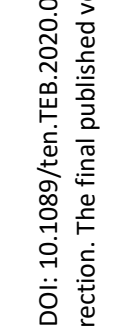 & Liu et al., $2016^{59}$ & $\begin{array}{c}\text { Mandible } \\
\text { alveolar } \\
\text { buccal plate } \\
\text { defect* }\end{array}$ & 6 months & $\begin{array}{l}\text { cBMSCs/HA- } \\
\text { collagen }\end{array}$ & $\begin{array}{c}\text { Histology } \\
\text { Histomorphometry } \\
\mu \mathrm{CT}\end{array}$ \\
\hline 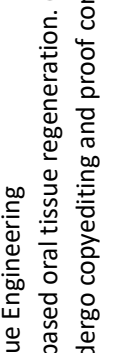 & $\begin{array}{l}\text { Luo et al., } 2016 \\
\qquad 60\end{array}$ & $\begin{array}{c}\text { Mandible class } \\
\text { II furcation } \\
\text { defect*** }\end{array}$ & 8 weeks & $\begin{array}{c}\text { ESEHT- PAB } \\
\text { / not specified } \\
\text { two graft } \\
\text { materials }\end{array}$ & $\begin{array}{c}\text { Histology } \\
\text { Histomorphometry }\end{array}$ \\
\hline 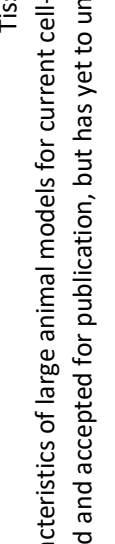 & $\begin{array}{l}\text { Zhu et al., } 2017 \\
61\end{array}$ & $\begin{array}{l}\text { Mandible and } \\
\text { maxillary third } \\
\text { premolar, } \\
\text { fourth } \\
\text { premolar and } \\
\text { first molar } \\
\text { defect** }\end{array}$ & 8 weeks & $\begin{array}{l}\text { Beta-defensin-3- } \\
\text { cPDLCs sheets }\end{array}$ & $\begin{array}{c}\text { Histology, } \\
\text { Immunohistochemistry }\end{array}$ \\
\hline 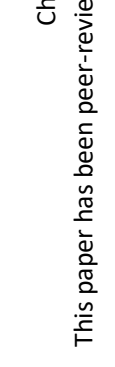 & Shi et al., $2018^{62}$ & $\begin{array}{c}\text { Mandible } \\
\text { second } \\
\text { premolars } \\
\text { buccal plate } \\
\text { dehiscence* }\end{array}$ & 12 weeks & hPDLCs/BCP & $\begin{array}{c}\text { Hstology } \\
\text { flurescence } \\
\text { microscopy } \mu \mathrm{CT}\end{array}$ \\
\hline & Rezaei et al., & Mandible and & 8 weeks & GFP transfected & Histology \\
\hline
\end{tabular}


48

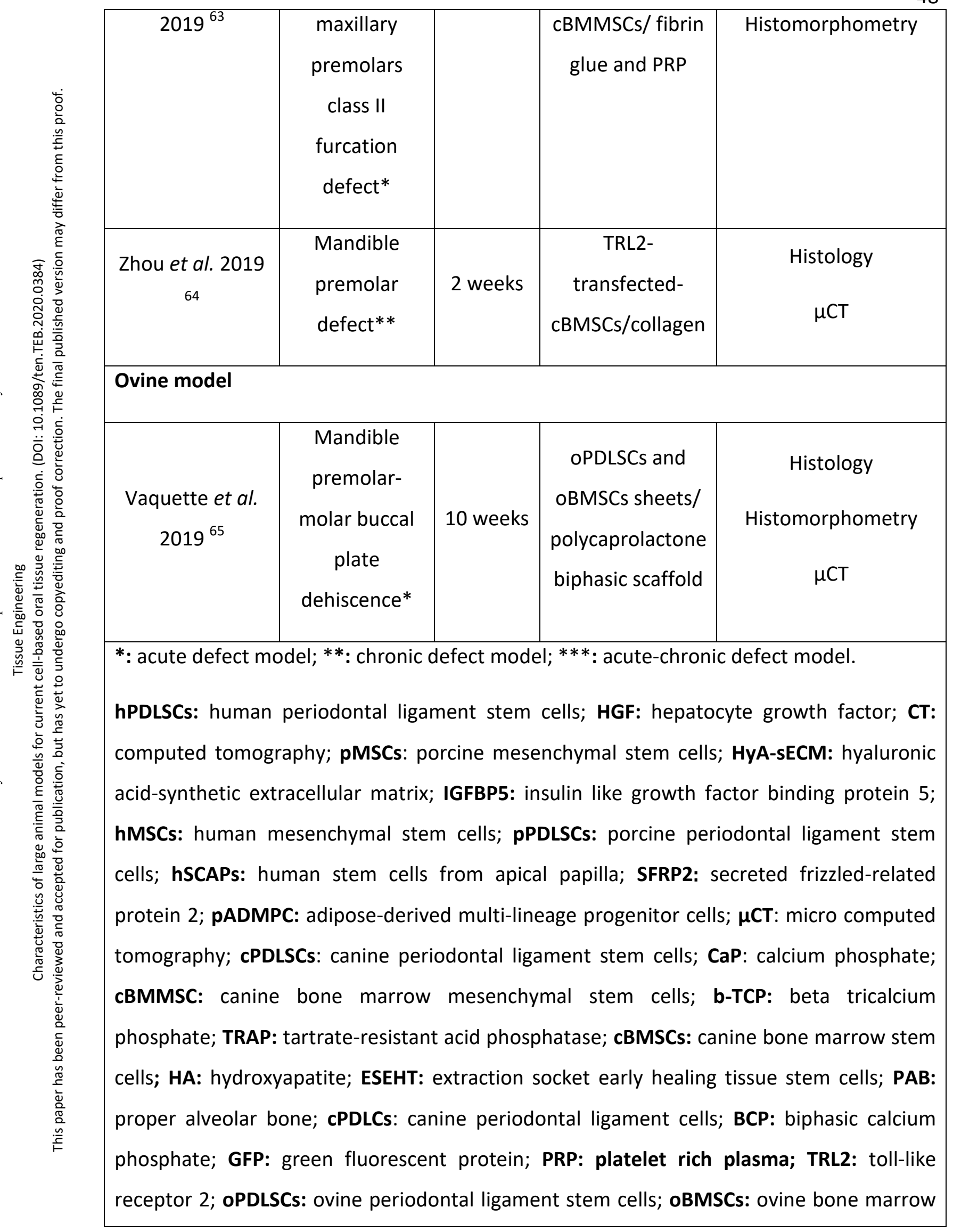


Page 49 of 54

49

stem cells

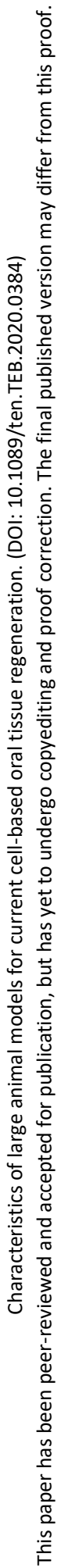


Table 4. Dentin-pulp complex regeneration.

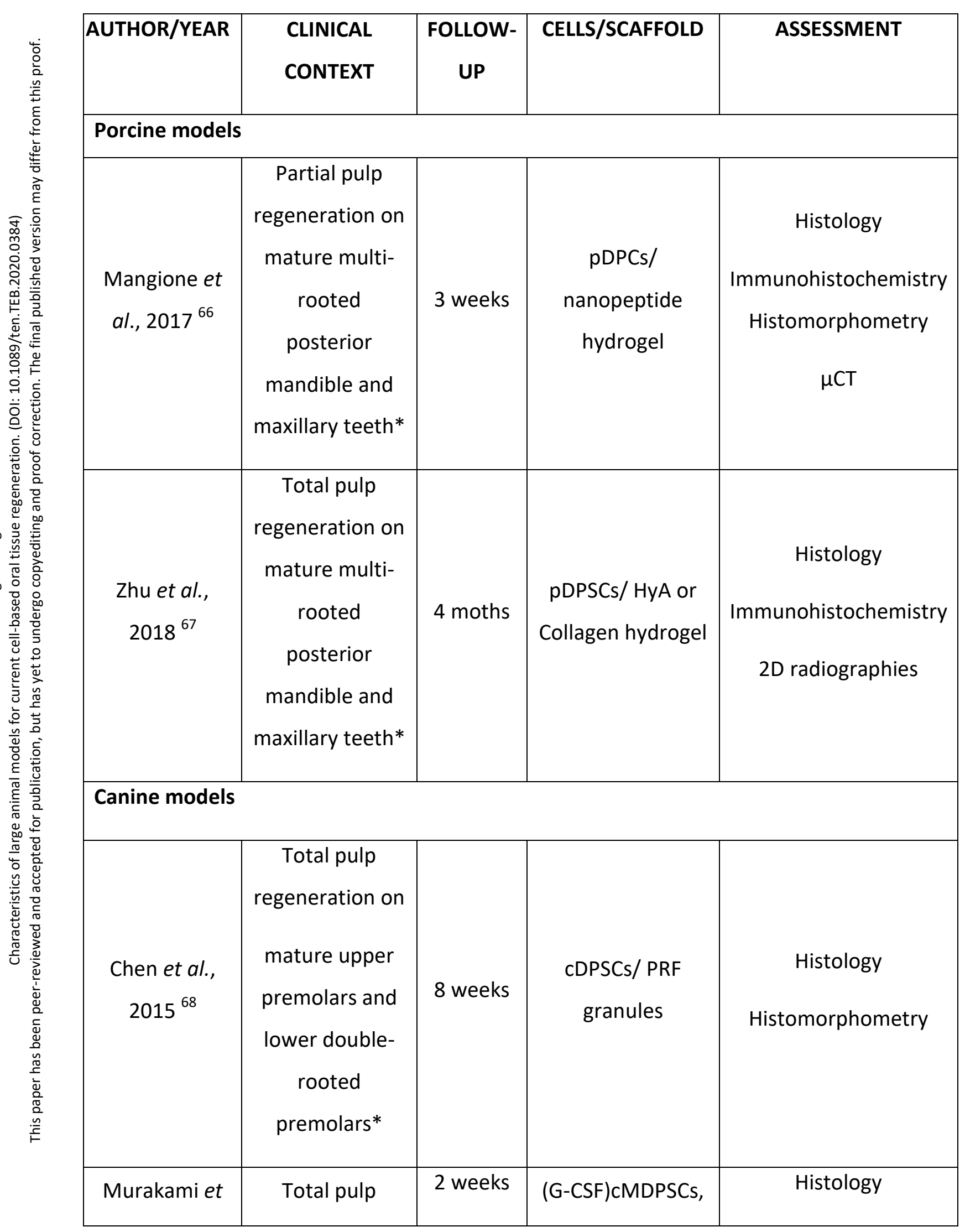




\begin{tabular}{|c|c|c|c|c|c|}
\hline 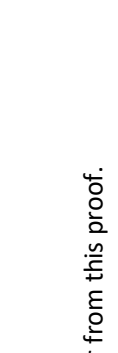 & al., $2015^{69}$ & $\begin{array}{l}\text { regeneration on } \\
\text { mature upper } \\
\text { and lower } \\
\text { incisors* }\end{array}$ & & $\begin{array}{l}\text { (G-CSF)cMBMSCs, } \\
\text { (G-CSF)cMADSCs } \\
\text { / atelocollagen }\end{array}$ & $\begin{array}{l}\text { Histomorphometry } \\
\text { In situ hybridization } \\
\text { Immunohistochemistry }\end{array}$ \\
\hline 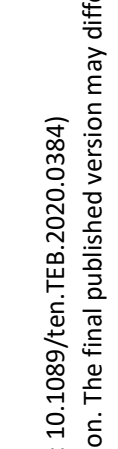 & $\begin{array}{c}\text { lohara et al., } \\
2016^{70}\end{array}$ & $\begin{array}{l}\text { Total pulp } \\
\text { regeneration on } \\
\text { mature lower } \\
\text { second and } \\
\text { third incisors* }\end{array}$ & 180 days & $\begin{array}{c}\text { (G-CSF)cMDPSCs/ } \\
\text { atelocollagen }\end{array}$ & $\begin{array}{l}\text { Histology } \\
\text { MRI }\end{array}$ \\
\hline 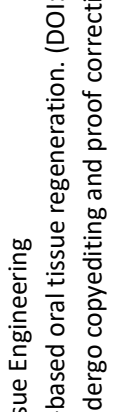 & $\begin{array}{c}\text { Jia et al., } 2016 \\
71\end{array}$ & $\begin{array}{l}\text { Partial pulp } \\
\text { regeneration on } \\
\text { immature upper } \\
\text { and lower } \\
\text { premolars* }\end{array}$ & 10 weeks & $\begin{array}{l}\text { SIM + cDPSCs } \\
\text { +absorbable } \\
\text { gelatin sponge }\end{array}$ & $\begin{array}{c}\text { Histology } \\
\text { 2D radiographies }\end{array}$ \\
\hline 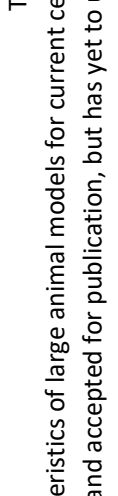 & $\begin{array}{c}\text { Bakhtiar et al., } \\
2017^{72}\end{array}$ & $\begin{array}{l}\text { Pulp chamber } \\
\text { floor } \\
\text { perforation on } \\
\text { mature upper } \\
\text { and lower } \\
\text { premolars* }\end{array}$ & 3 months & $\begin{array}{c}\text { cDPSCs/TDM or } \\
\text { TCP }\end{array}$ & $\begin{array}{l}\text { Histology } \\
\text { Histomorphometry }\end{array}$ \\
\hline 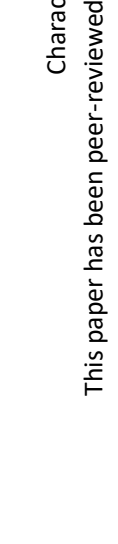 & 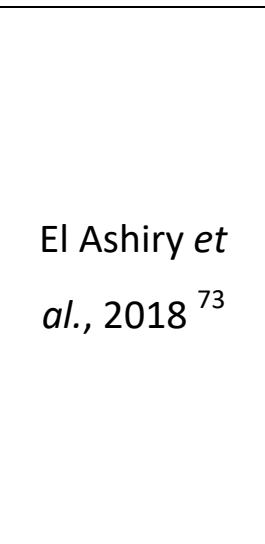 & $\begin{array}{l}\text { Total pulp } \\
\text { regeneration on } \\
\text { immature } \\
\text { necrotic upper } \\
\text { incisors with } \\
\text { periapical } \\
\text { periodontitis** }\end{array}$ & 4 months & $\begin{array}{c}\text { cDPSCs / chitosan } \\
\text { hydrogel + VEGF- } \\
\text { 2, PDGF, NGF, } \\
\text { BMP7 }\end{array}$ & $\begin{array}{l}\text { Histology } \\
\text { 2D radiographies }\end{array}$ \\
\hline
\end{tabular}




\begin{tabular}{|c|c|c|c|c|}
\hline $\begin{array}{c}\text { lohara et al., } \\
2018^{74}\end{array}$ & $\begin{array}{l}\text { Total pulp } \\
\text { regeneration on } \\
\text { mature upper } \\
\text { and lower } \\
\text { incisors* }\end{array}$ & 12 weeks & $\begin{array}{l}\text { cMDPSCs with } \\
\text { DLA/atelocollagen }\end{array}$ & $\begin{array}{l}\text { Histology } \\
\text { Blood tests } \\
\text { Urine tests }\end{array}$ \\
\hline $\begin{array}{l}\text { El-Zekrid et } \\
\text { al., } 2019^{75}\end{array}$ & $\begin{array}{c}\text { Partial pulp } \\
\text { regeneration on } \\
\text { mature upper } \\
\text { and lower } \\
\text { multi-rooted } \\
\text { teeth* }\end{array}$ & 9 weeks & Injected cBMSCs & Histology \\
\hline
\end{tabular}

*: acute defect model; ${ }^{* *}$ : chronic defect model; ${ }^{* *}$ : acute-chronic defect model.

pDPC: porcine dental pulp cells; $\mu \mathrm{CT}$ : micro computed tomography; pDPSCs: porcine dental pulp stem cells; HyA: Hyaluronic acid; 2D: bidimensional; PRF: platelet rich fibrin; (G-CSF)cMDPSCs: granulocyte-colony stimulating factor mobilized dental pulp stem cells; (G-CSF)cMBMSCs: granulocyte-colony stimulating factor canine mobilized bone marrow stem cells; (G-CSF)cMADSCs: granulocyte-colony stimulating factor canine mobilized adipose derived stem cells; MRI: magnetic resonance imaging; SIM: simvastatin; TDM: treated dentin matrix; TCP: tricalcium phosphate; VEGF-2: vascular endothelial growth factor-2; PDGF: Platelet-derived growth factor; NGF: nerve growth factor; BMP7: bone morphogenetic protein-7; DLA: dog leukocyte antigen; cBMSCs: canine bone marrow stem cells. 
Table 5. Tooth/ tooth root regeneration.

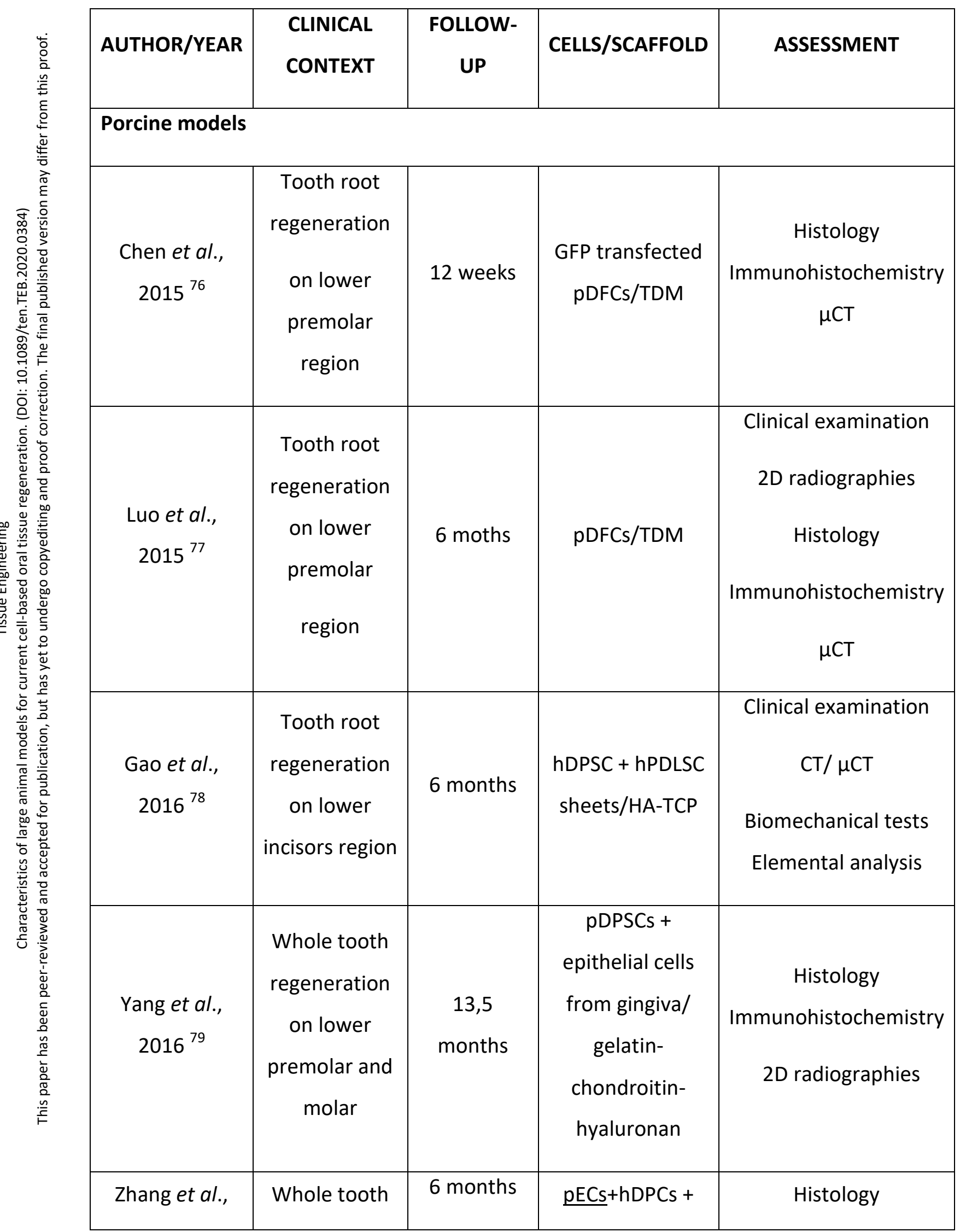


54

\begin{tabular}{|c|c|c|c|c|c|}
\hline 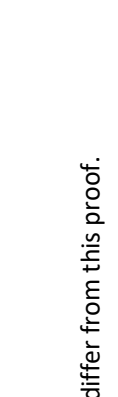 & $2017^{80}$ & $\begin{array}{c}\text { regeneration } \\
\text { on lower } \\
\text { canine and } \\
\text { premolar } \\
\text { region }\end{array}$ & & hUVEC/ dTBs & $\begin{array}{c}\text { Immunohistochemistry } \\
\mu \mathrm{CT}\end{array}$ \\
\hline 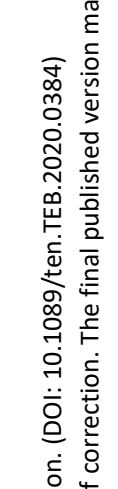 & $\begin{array}{l}\text { Wu et al., } 2019 \\
81\end{array}$ & $\begin{array}{l}\text { Whole tooth } \\
\text { regeneration } \\
\text { on upper } \\
\text { incisor, canine } \\
\text { and premolar } \\
\text { region }\end{array}$ & 150 days & $\begin{array}{l}\text { Re-associated } \\
\text { human tooth } \\
\text { germs cells and } \\
\text { systemically } \\
\text { infused } \\
\text { hBMMSCs }\end{array}$ & $\begin{array}{c}\text { Histology } \\
\text { Immunohistochemistry } \\
\text { CT } \\
\text { CBCT }\end{array}$ \\
\hline 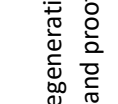 & \multicolumn{5}{|l|}{ Canine model } \\
\hline 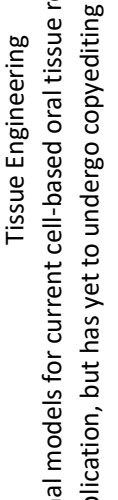 & $\begin{array}{l}\text { Ono et al., } \\
2017^{82}\end{array}$ & $\begin{array}{l}\text { Whole tooth } \\
\text { regeneration } \\
\text { on lower } \\
\text { premolar } \\
\text { region }\end{array}$ & $\begin{array}{l}180 \text { days } \\
\text { (+ } 30 \text { days } \\
\text { of } \\
\text { orthodontic } \\
\text { treatment) }\end{array}$ & $\begin{array}{l}\text { Canine tooth } \\
\text { buds cells }\end{array}$ & $\begin{array}{c}\text { Histology } \\
\text { CBCT/ } \mu \mathrm{CT} \\
\text { SEM } \\
\text { Energy-dispersive X- } \\
\text { ray spectroscopy }\end{array}$ \\
\hline 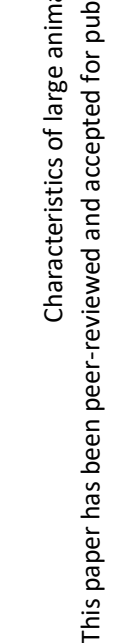 & \multicolumn{5}{|c|}{$\begin{array}{l}\text { GFP: green fluorescent protein; pDFCs: porcine dental follicles cells; TDM: treated dentin } \\
\text { matrix; } \boldsymbol{\mu C T} \text { : micro computed tomography; 2D: bidimensional; hDPSC: human dental pulp } \\
\text { stem cells; hPDLSC: human periodontal ligament stem cells; HA-TCP: hydroxyapatite- } \\
\text { tricalcium phosphate; CT: computed tomography; pDPSCs: porcine dental pulp stem cells; } \\
\text { pECs: porcine epithelial cells; hDPCs: human dental pulp cells; hUVECs: human umbilical } \\
\text { vein endothelial cells; dTBs: decellularized tooth buds; hBMMSCs: human bone marrow } \\
\text { mesenchymal stem cells; CBCT: cone beam computed tomography; SEM: scanning } \\
\text { electron microscopy. }\end{array}$} \\
\hline
\end{tabular}

